\title{
PAUL E. POTTER: HIS YEARS AT CINCINNATI, INTERWOVEN WITH THE IL, IN, OH, AND KY STATE SURVEYS
}

J. Barry Maynard, Craig Dietsch and Dan Sturmer Department of Geology, University of Cincinnati, Cincinnati, OH 45221-0013 


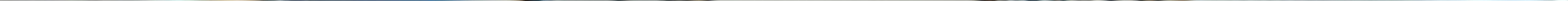




\section{Antecedents and Early Years}

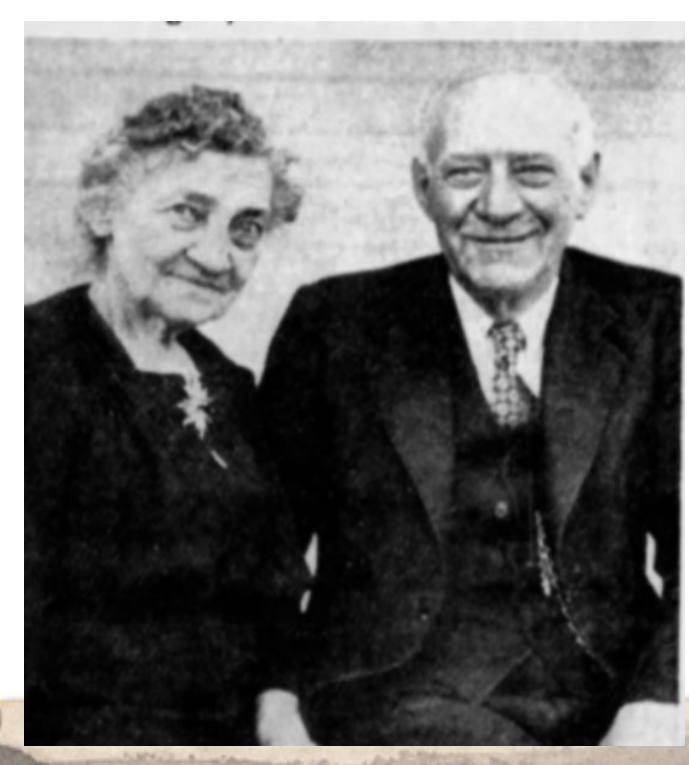

Charles and Zenobia Yanser, maternal grandparents.

Charles was a prominent politician in Slatington PA, and was the manager of a slate quarry. Shown below is a typical slate operation in the Lehigh Valley

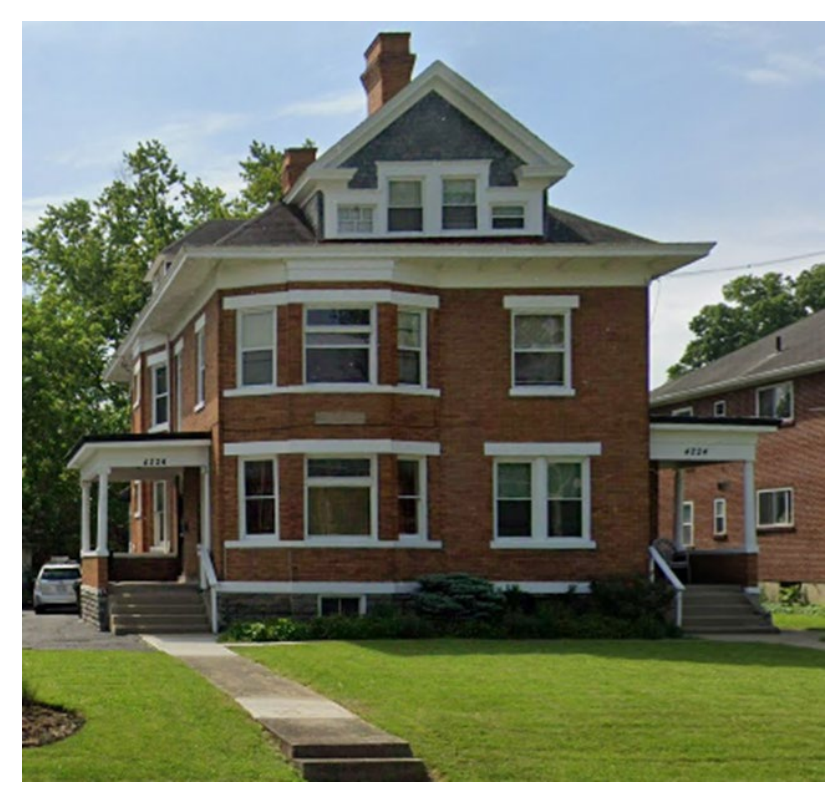

Boyhood home in Norwood OH

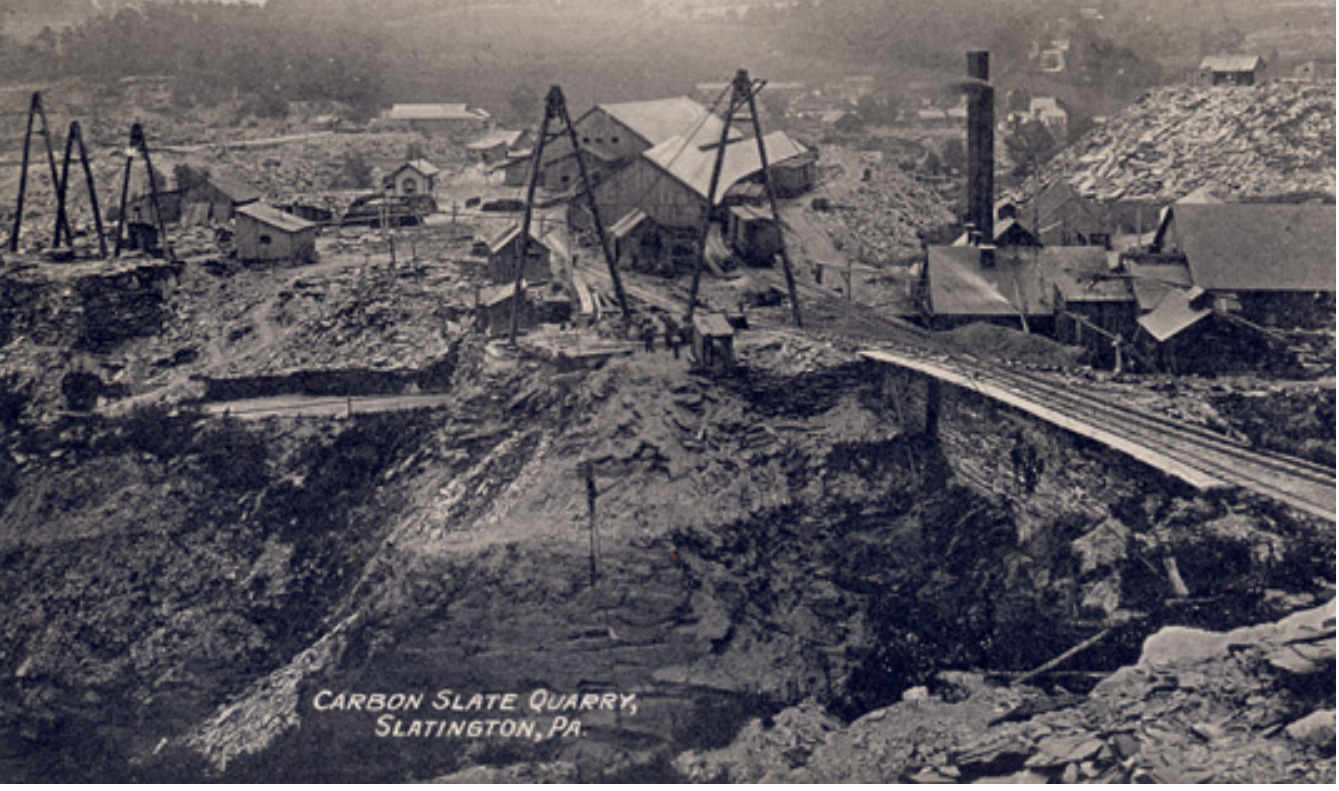

Paul's father, Edwin Forrest Potter was in the retail shoe business, with a store in downtown Cincinnati on Race Street, specializing in orthopedic shoes for women

\section{SALE:}

427 Pairs Regularly 11.75 to 12.75

Dr. LOCKE Women's SHOES - 13

Our ONLY SALE This Year!

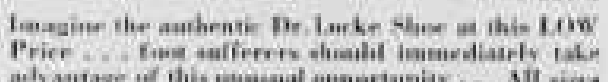

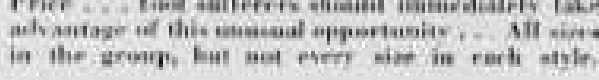
EDWIN POTIER SERVICE-

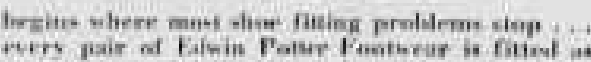

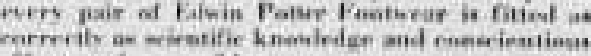
etrert makr pinalis.

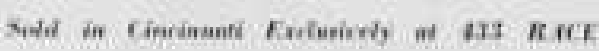

EPWTIN F. POTJER INC.

Shoes for thaphiness 


\section{EDUCATION}

- Two-room school for $5^{\text {th }}-8^{\text {th }}$ grades

- High School at Anderson High senior year at UC in joint HS/ College program

- US Army in Philippines - enlisted 1944. Discharged mid 1946

- U of Chicago on GI Bill - 19461953. PhD thesis on Lafayette Gravel
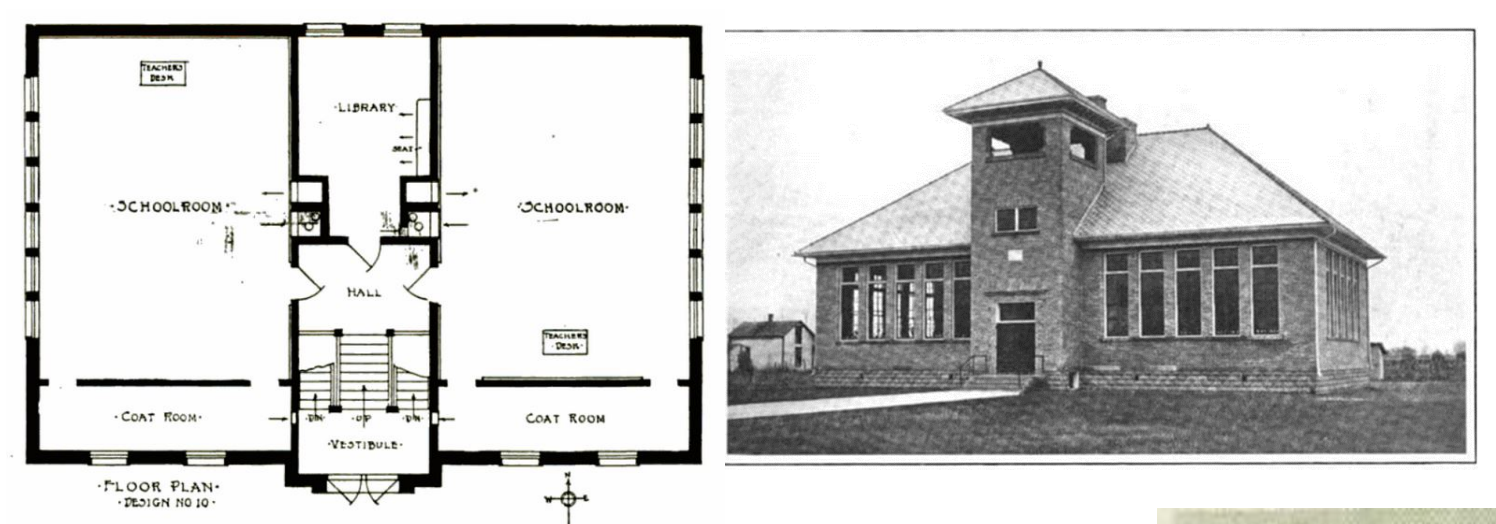

Typical Ohio two-room schoolhouse
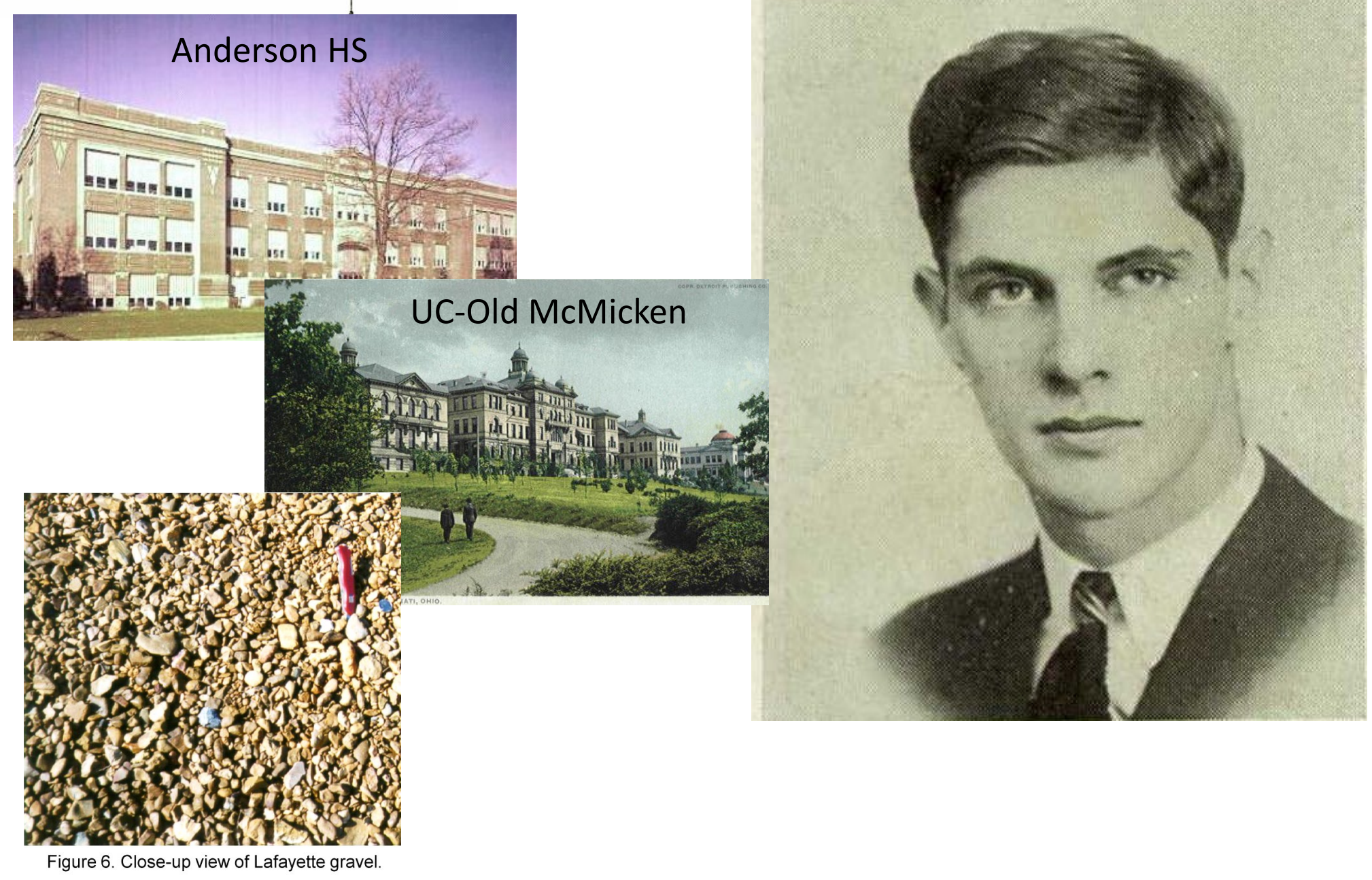


\section{US Army - Jan 1944 - summer 1946}

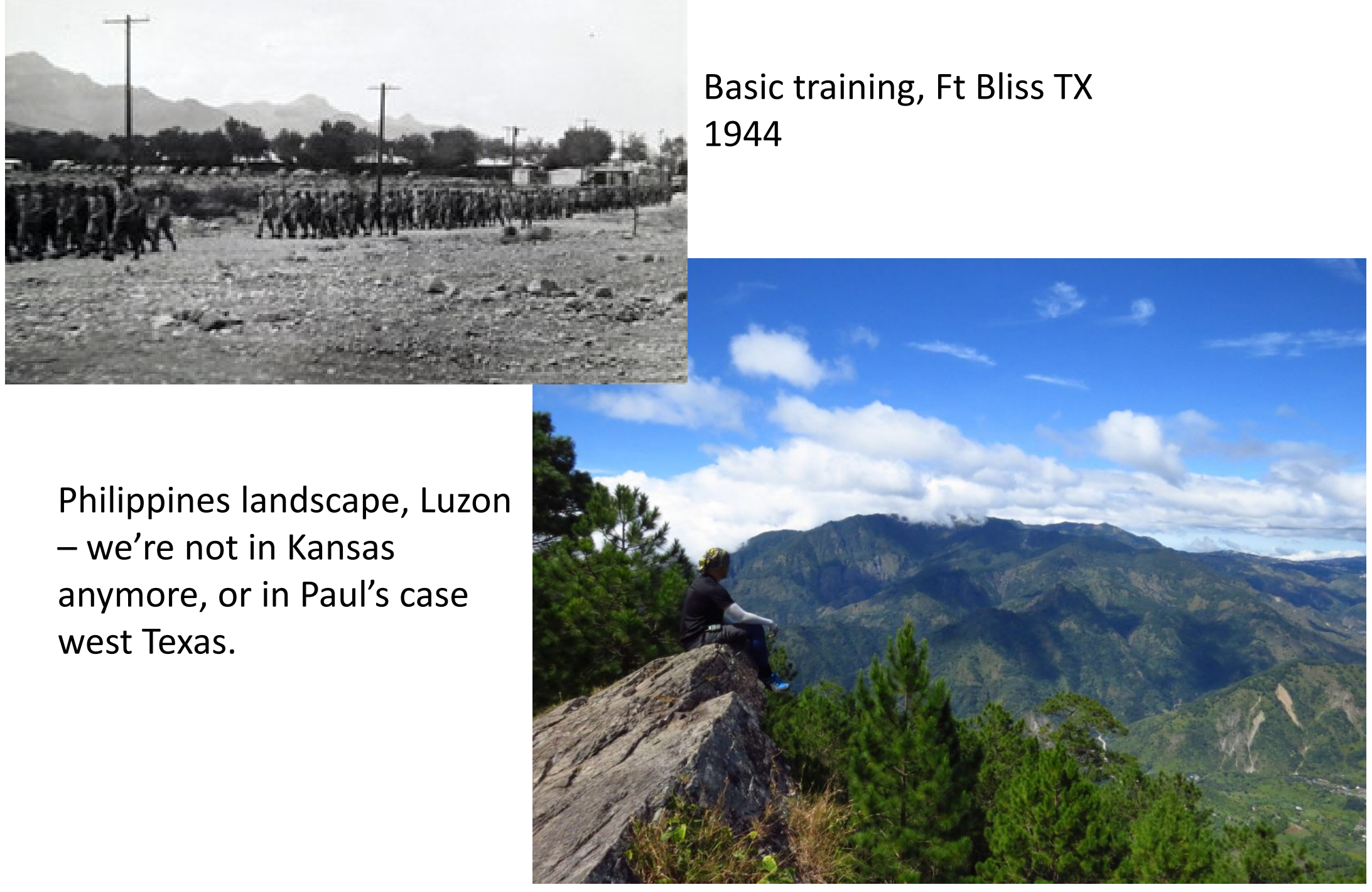

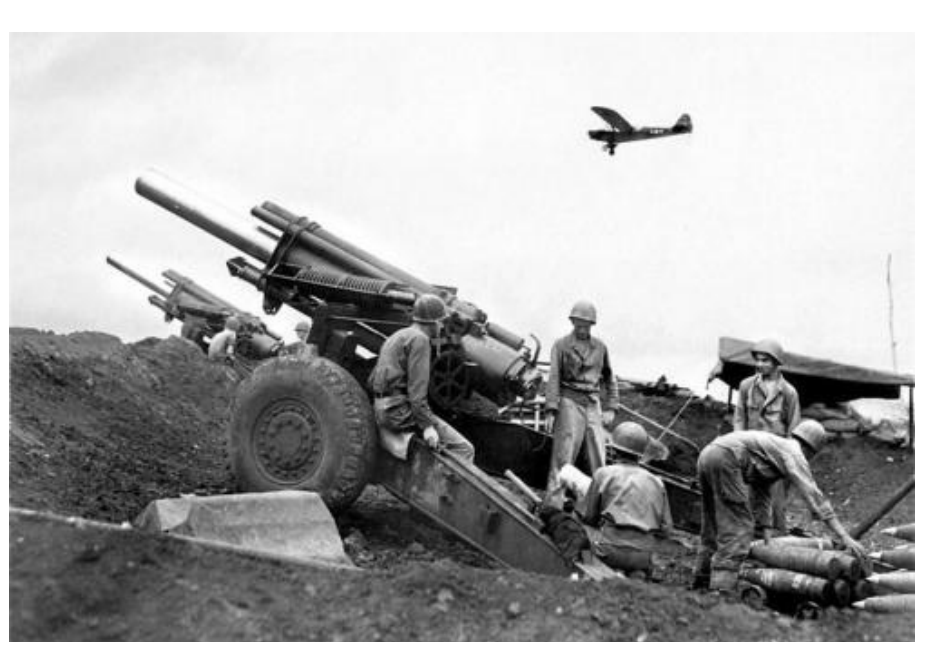

$155 \mathrm{~mm}$ howitzer in action Philippines 1944.

Paul was a PFC in a small detachment (one lieutenant, one sergeant, and two privates) acting as forward artillery observers for a $155 \mathrm{~mm}$ howitzer battery. 
Illinois - The Geological Survey - 1952-1961
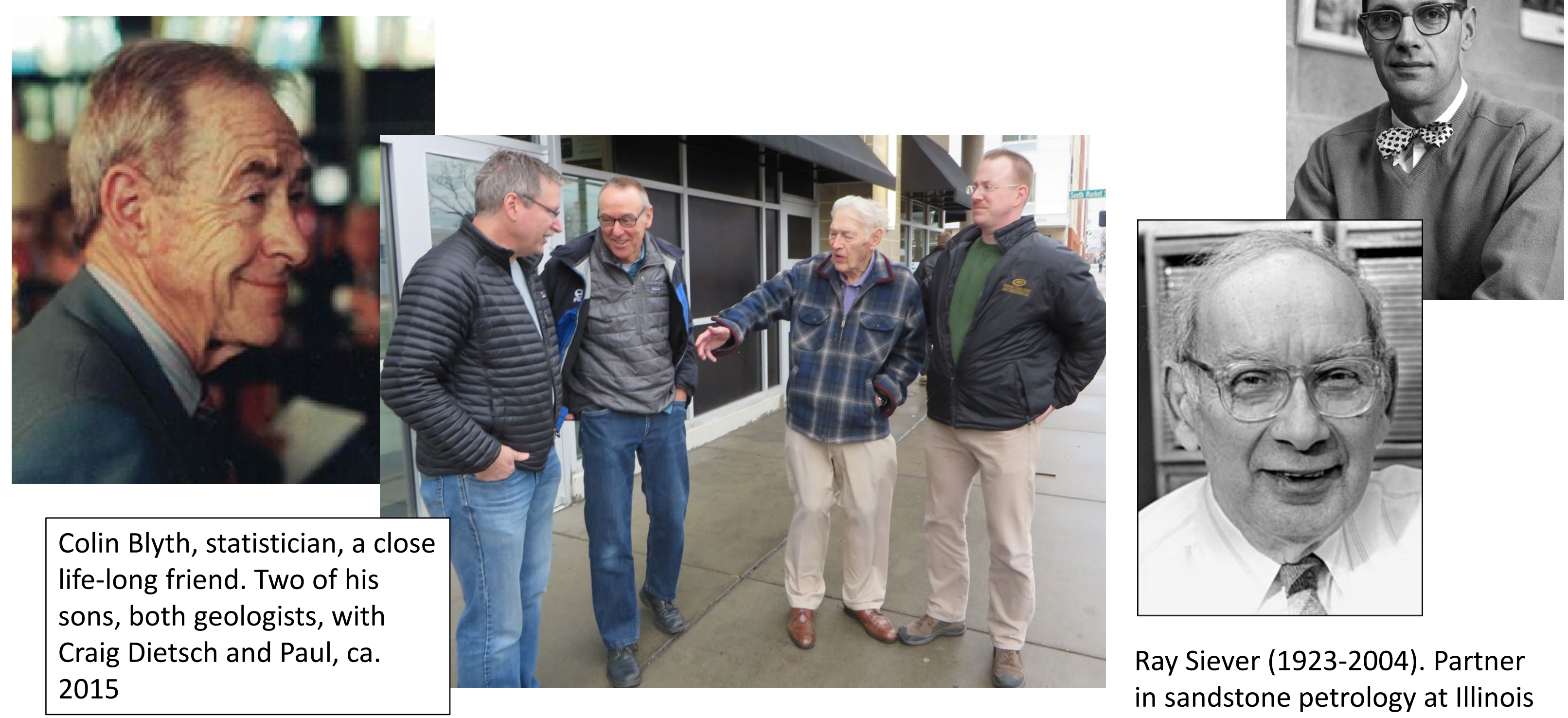

Ray Siever (1923-2004). Partner in sandstone petrology at Illinois State Geological Survey 


\section{Some examples of projects at IGS from the Potter-Siever team}

SOURCES OF BASAI PENNSYLVANIAN SEDIMENTS IN THE EASTERN INTERIOR BASIN

$$
\text { 1. CROSS-BEDDING }{ }^{1}
$$
PENNSYLVANIAN STRATIGRAPHIC VARIABILITY

$$
\text { PAUL EDWIN POTTER AND RAYMOND SIEVER }
$$

PAUL EDWIN POTTER AND RAYMYOND SIEVER 2

$$
\text { Urbana, Illinois }
$$

$$
\text { ABSTRACT }
$$

The long distance separating the basal Pennsylvanian sedirents of the Eastern Interior Basin from
possible major source areas combines with mineralogic maturity to make solution of the source-area problem

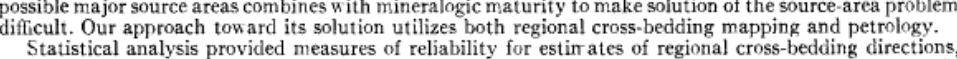
Statistical analysis provided measures of reliability for estitin ates of regional cross-bedding directions
estimated the variability arising from levels of subsampling, and made possibbe esignificant economies in

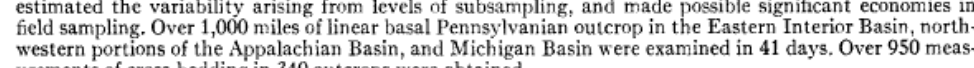
wertern portions of the Appalachinin Basin, and Mictingan Dasin were examined in 41 days. Over 90 meas
urements of cross-bedding in 340 outcrops were obtained.
The

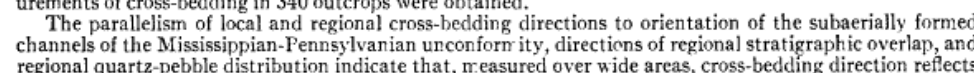
regional quartz-pebble distribution indicate that, neasured over wide arcas, cross-bedding direction retiects
the repional slope from the surce area
Based on this hyposthesis, the basal Pennsylvanian sediments of the Eastern Interior Basin had a minor

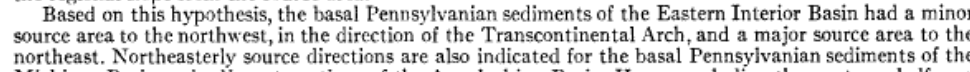

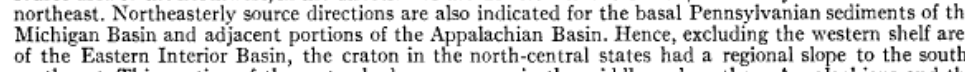

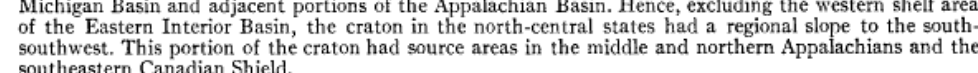

INTRODUCTION

The purpose of this study is to demonstrate a regional method of sedimentThe inivilual elements of this meththreefold (1) ration. Ths essentials are of the application of statistics, not new; direction (1) a number of investigators have made as cross beddin the studies of either directional properties or as cross-bedding, low, or mple mark to mineralogy. But the combined study of transport (2) systematic regional petrol- directional structures and petrology on a ogy to establish regional mineral associa- regional basis is just beginning. Two extions; and (3) use of statistics as a guide amples of the application of this methodto sampling effort, to provide measures ology to areas of moderate size are the 1 published by permission of the Chief, lllinois combination cross-bedding and petrologic 1 Published by permission of the Chief, Illinois studies of Lemcke, Von Engelhardt, and
Geological Survey, Urbana. Manuscript received June 23, 1955 $2_{\text {Associate geologist and geologist, Illinois Geo- }}$
logical Survey. uchtbauer (1953) and of Potter (1955). 3 We use the tern directional structure to include tion the basal Pennsylvanin all those sedimentary structures which have direc- of the Eastern Interior Basin provide an ticanal signiificance and to differentiate them from ideal test for this methodology. Because scalar sedimentary properties, such as grain-size the Eastern Interior Basin is far removed
distributions, mud cracks, etc.

\section{THE JOURNAL OF GEOLOGY}

July 1956

SOURCES OF BASAL PENNSYLVANIAN SEDIMENTS IN THE EASTERN INTERIOR BASIN

2. SEDIMENTARY PETROLOGY RAYMOND SIEVER AND PAUL EDWIN POTTER ${ }^{2}$ Urbana, Illinois ABSTRACT

Sedimentary petrology was used in this provenance study to map regional mineral associations and to
indicate the composition and tectonic states of their source areas. Quantitative estimates of tourmaline

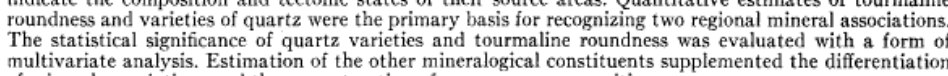

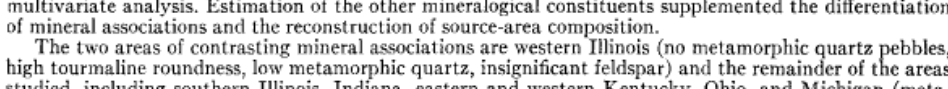
high tourmaline roundness, low metamorphic quartz, insignificant feldspar) and the remainder of the areas
studied, including southern IIllinois, Indiana, eastern and western Kentuckty, Ohio, and Michigan (meta-

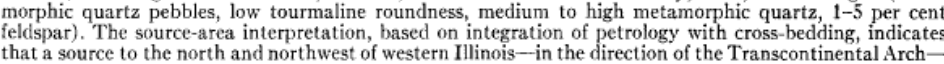

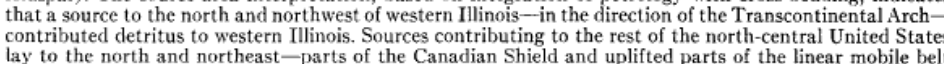

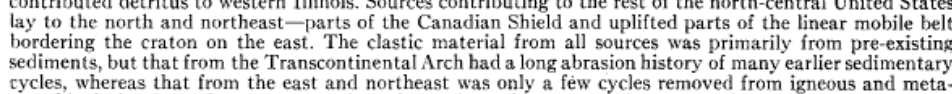

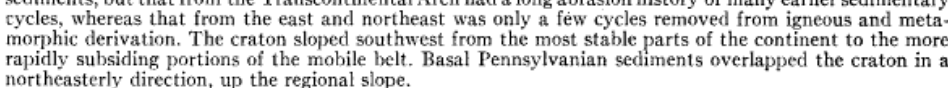

INTRODUCTION

Part 1 of this study (Potter and Siever,
$1956)$, a regional field study of cross-bed1956), a regional field study of cross-bed-
ding, indicated the transport pattern of the ding, indicated the transport pattern of the
basal Pennsylvanian sediments of the Eastern Interior Basin. In this part, sedimentary petrology is used to discriminate further between source areas and to assess source-are composition. Petrologic studies 'Published by permission of the Chief, Illinois
State Geological Survey, Urbana. Manuscript
received June 23, 1955 . 2'Geologist and Associate Geologist, Illinois
State Geological Survey. include those by Gault (1938) on the heavy (n) Mansfield of Indiana, by Michign Sharon of northern Ohio. Rittenhouse (1946) has studied the Sharon of Ohio and the Olean of New York. These studies have covered relatively restricted areas, and most There has been no previous broad regiona study of the sedimentary petrology of these The first objective of the petrographic study was to distinguish regional mineral mo related to contributions from 


\section{Characteristics}

- Think big. What is the larger framework for this work?

- Work big. Whole basin approach

- Combine surface and subsurface investigation

- Use multiple, quantitative techniques

- Do the statistics

- Work with state geological surveys 
Johns Hopkins 1962-63; Indiana University 1963-1970 - Migration to the Professoriate

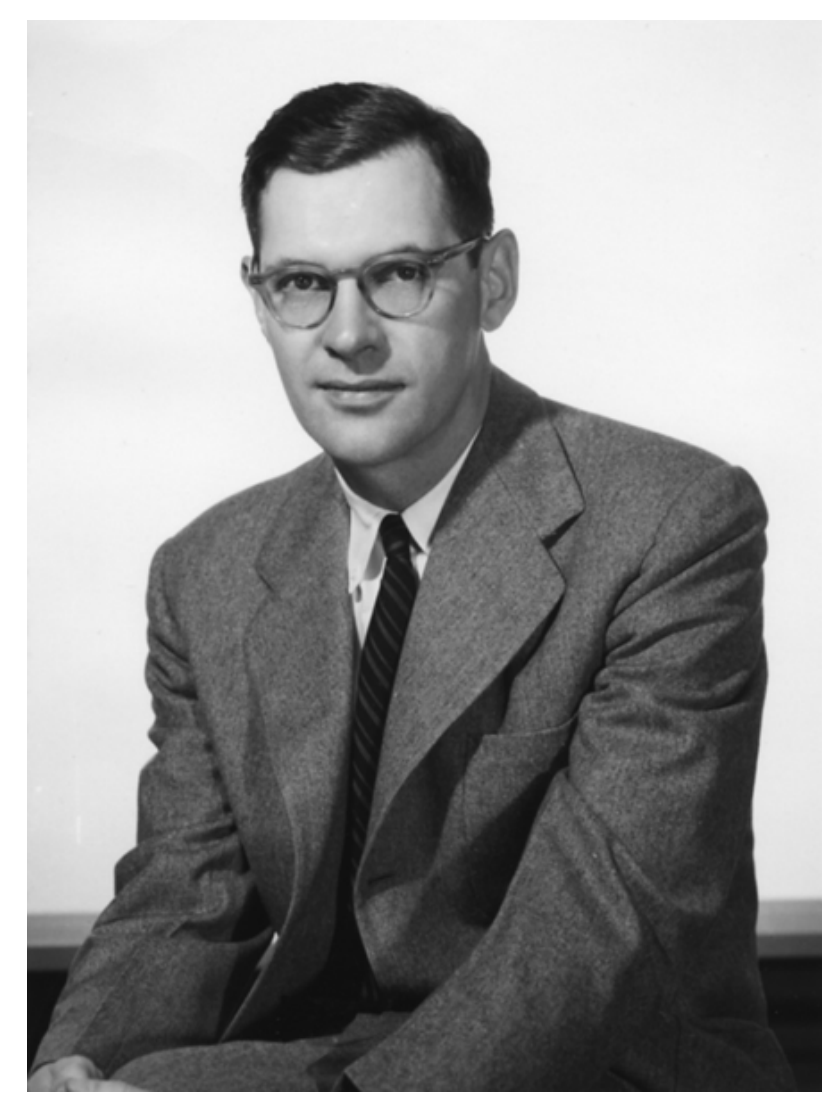

Books written at Hopkins and IU
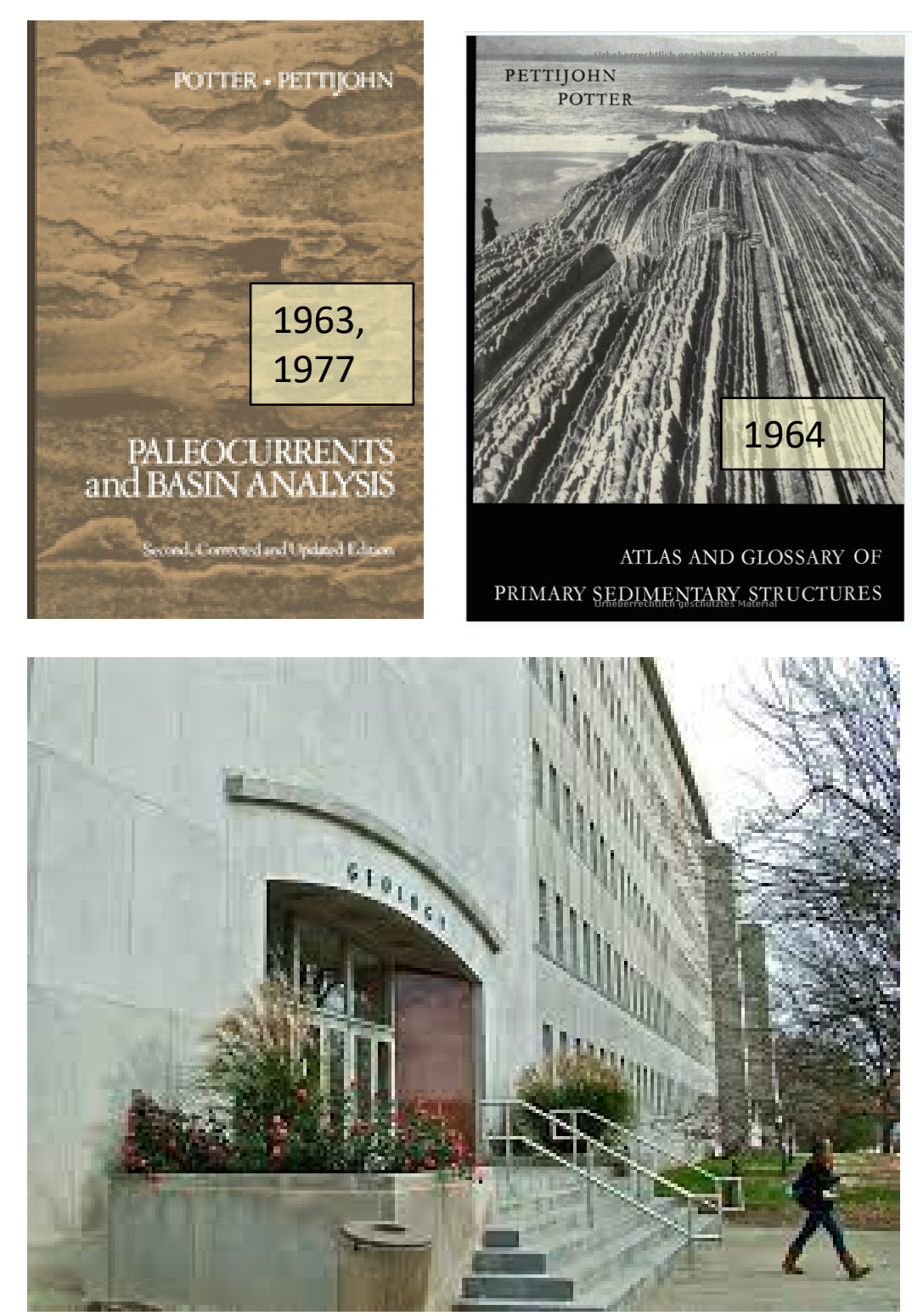
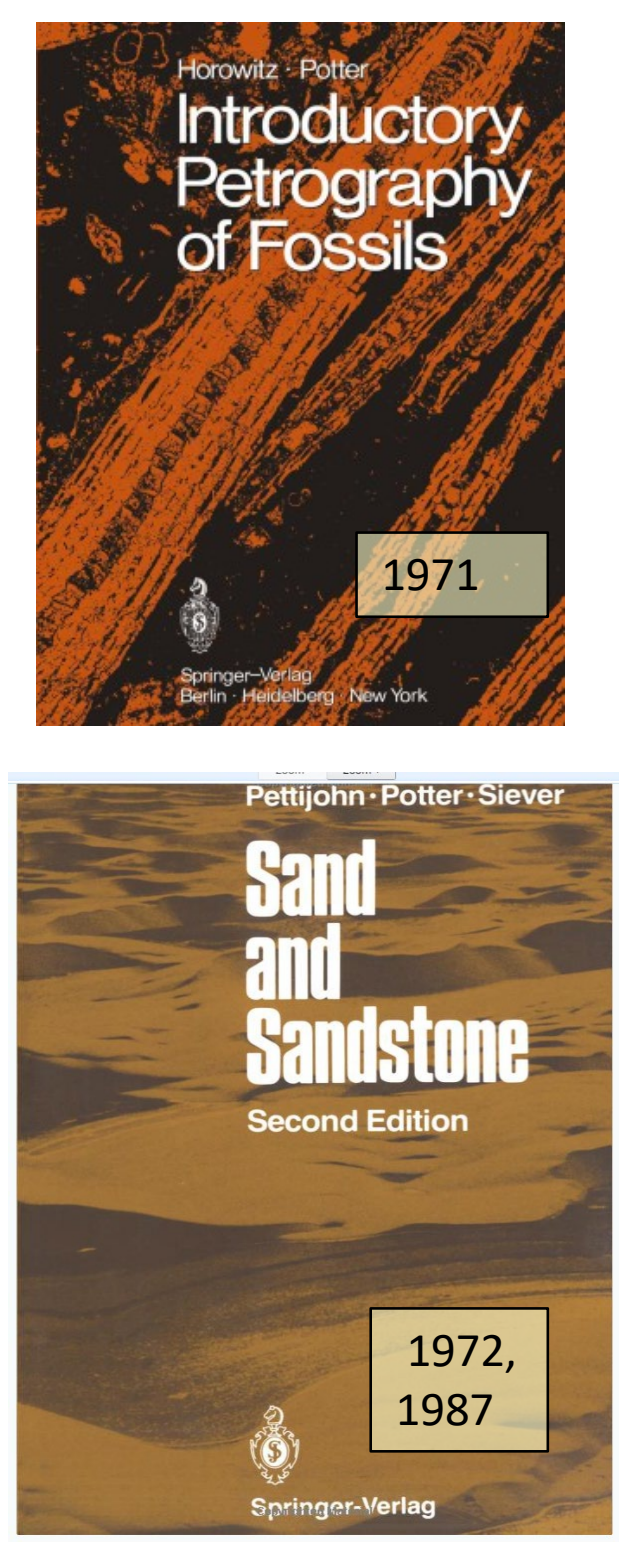


\section{Characteristics}

- Think world wide.

- Work big. Whole basin approach - use the basin as the integrating framework. Paleocurrents, petrography, geophysics, wire-line log signatures, sand-body geometry all tied together.

- Work collaboratively (and needle collaborators regularly) with faculty and state survey colleagues

- Write for a larger geologic audience; use clear illustrations with large fonts. For an example of the success of this approach, check out the following blog page by Elisabeth Kosters

https://earthsciencesociety.com/2013/11/26/the-king-of-sand-paul-edwin-potter/ 


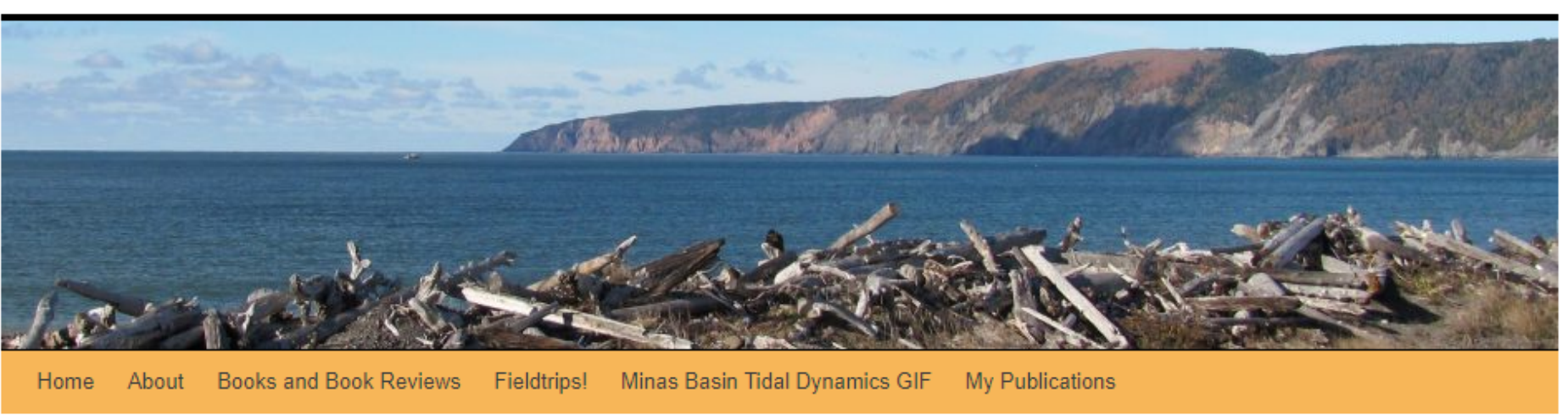

$\leftarrow$ SWITCH - The Future of Energy - @SwitchEProject C Canadian Earth Science for @PMHarper - Preamble $\rightarrow$

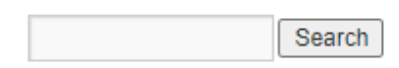

\section{The King of Sand: Paul Edwin Potter}

Posted on November 26, 2013 by earth science society.

I only ever truly loved two textbooks. I only ever loved these books because they were capable of captivating my attention, enhancing my understanding, and making me realize the depth of the subject. Most textbooks are poorly written encyclopedias that should be thrown out, no matter how beautiful they look and how famous their writers. No matter how relatively useful they are.

The first textbook I ever truly loved was 'Sand and Sandstone' by Francis Pettijohn, Paul Potter and Raymond Siever. It was first published in 1972 by Springer. I used a library copy during my MSc studies, wanted to own it right away, but couldn't afford it until I was a professional with a real salary. I bought it in 1984. The second edition was published in 1987 and you can still buy it for $\$ 239.00$ (ex shipping). YES! I am obviously not the only one: this must be a darn good book if Springer can still sell it for that price 26 years after it was published!

\section{This is a syndicated Science Borealis blog

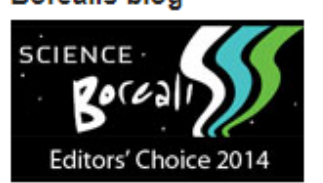

Recent Posts

- Sine-Saloum Delta, Senegal. A

tiny exploration.

- Our First Full Year under

Solar Power

- My Brilliant Career: a woman

geoscientist looks back (posted

on \#IWD2017)

- New Banner picture! Cobequid-

Chedabucto Fault at Cape

Chignecto, Nova Scotia

- Exxon, climate change and

sequence stratigraphy

Archives

Select Month v

Categories

- Canadian Earth Science fo

@PMHarper

- climate change

- coastal systems 
Crossing Over - The University of Cincinnati 1971-1992

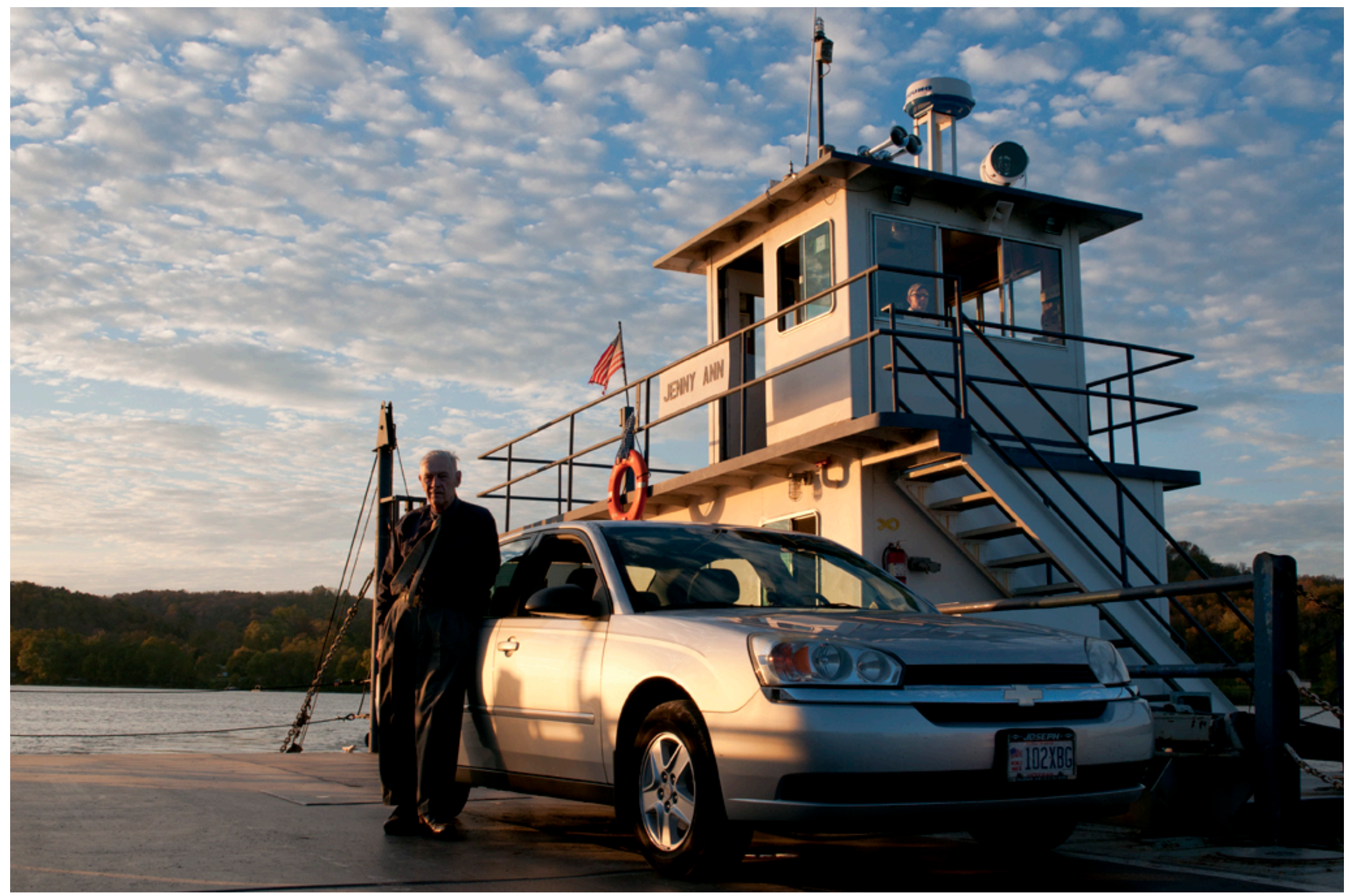




\section{New horizons, a new class of rocks}
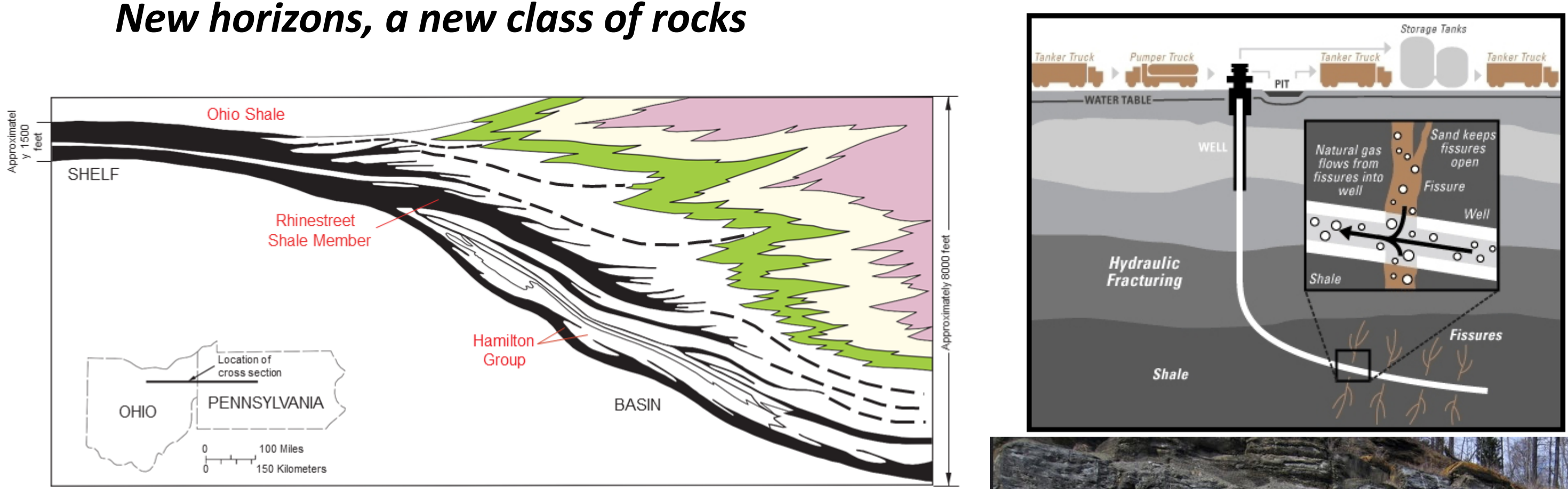

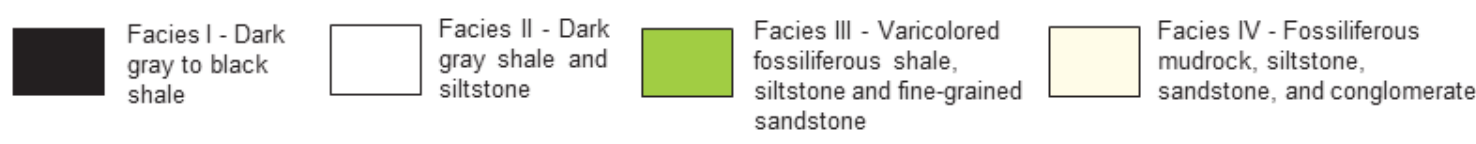

Facies V - Gray to red mudstone, siltstone,
sandstone and conglomerat

Hypothetical time line - -

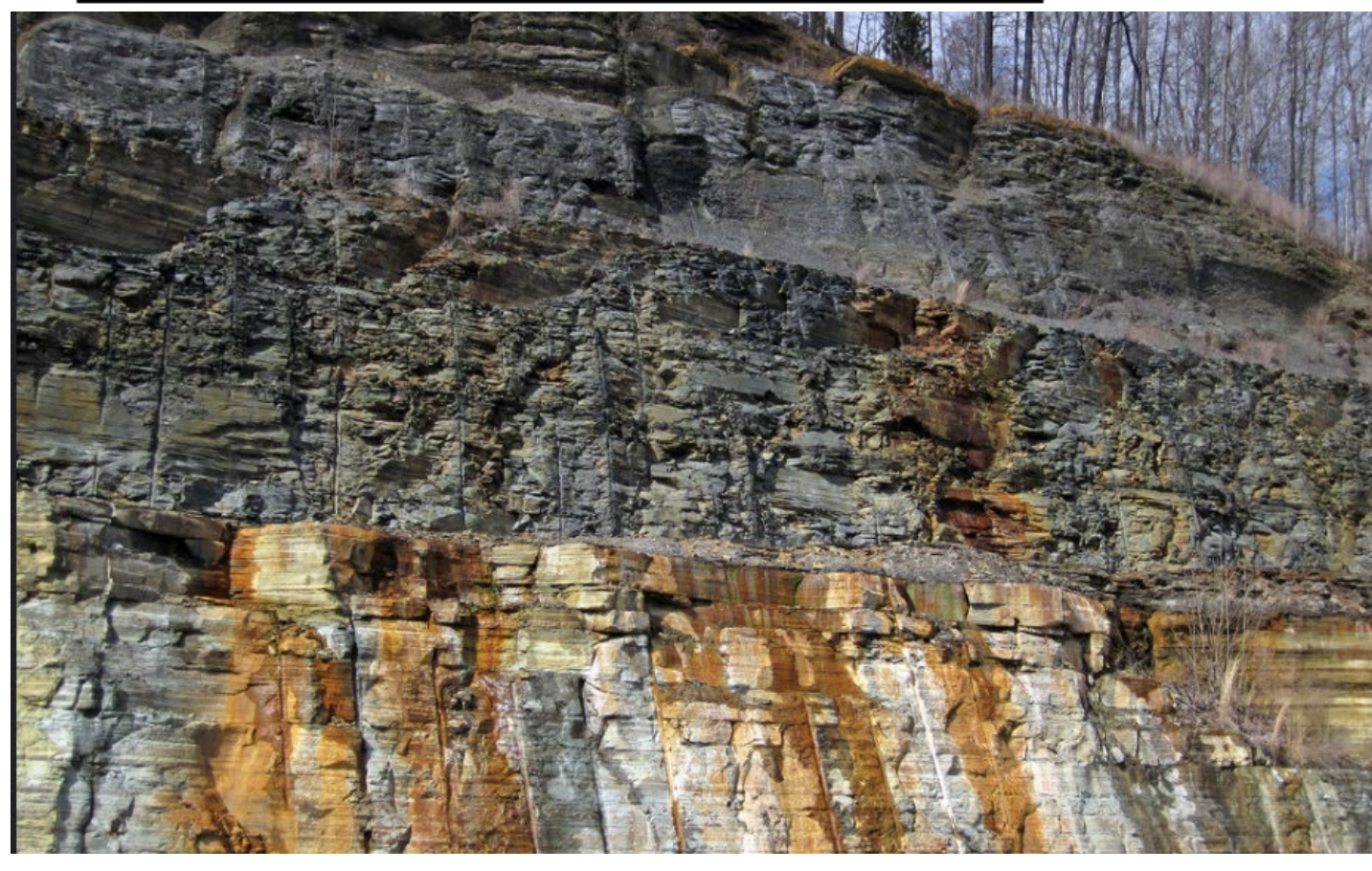




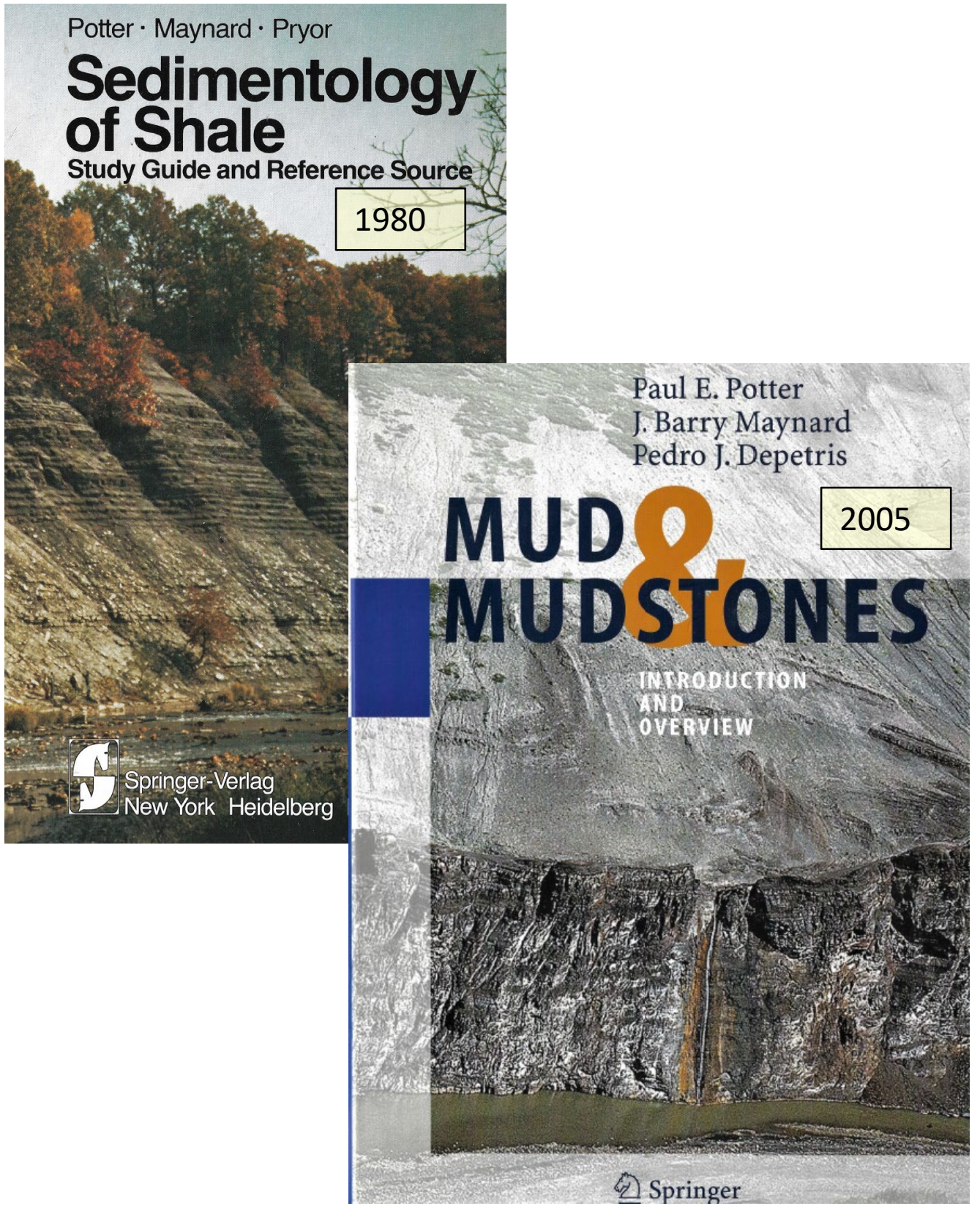

\section{Characteristics}

- Think big

- Cover the whole basin

- Combine surface and subsurface (make outcrop gamma-ray logs)

- Work closely with USGS, OH-KY-IN-ILWV surveys + other faculty

- Involve lots of graduate students

- Write for a larger audience - geologists and engineers 
Teaching-field work; petrography; cores

4-day field trip to southern Illinois; Paul's

microscope; student lab work on core description

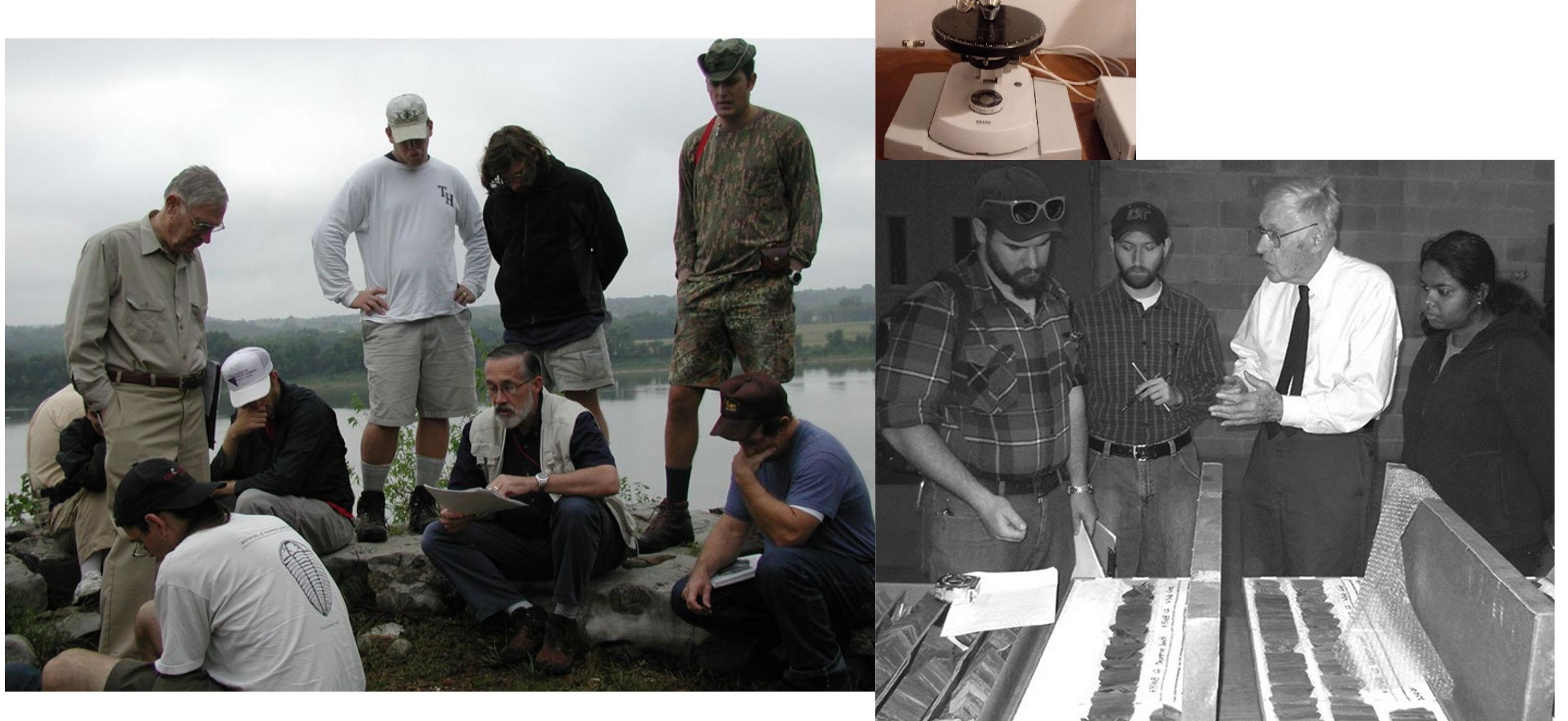




\section{COMMUNITY SERVICE: the City, the States - IL-IN-KY-OH; Countries - Brazil, the US}

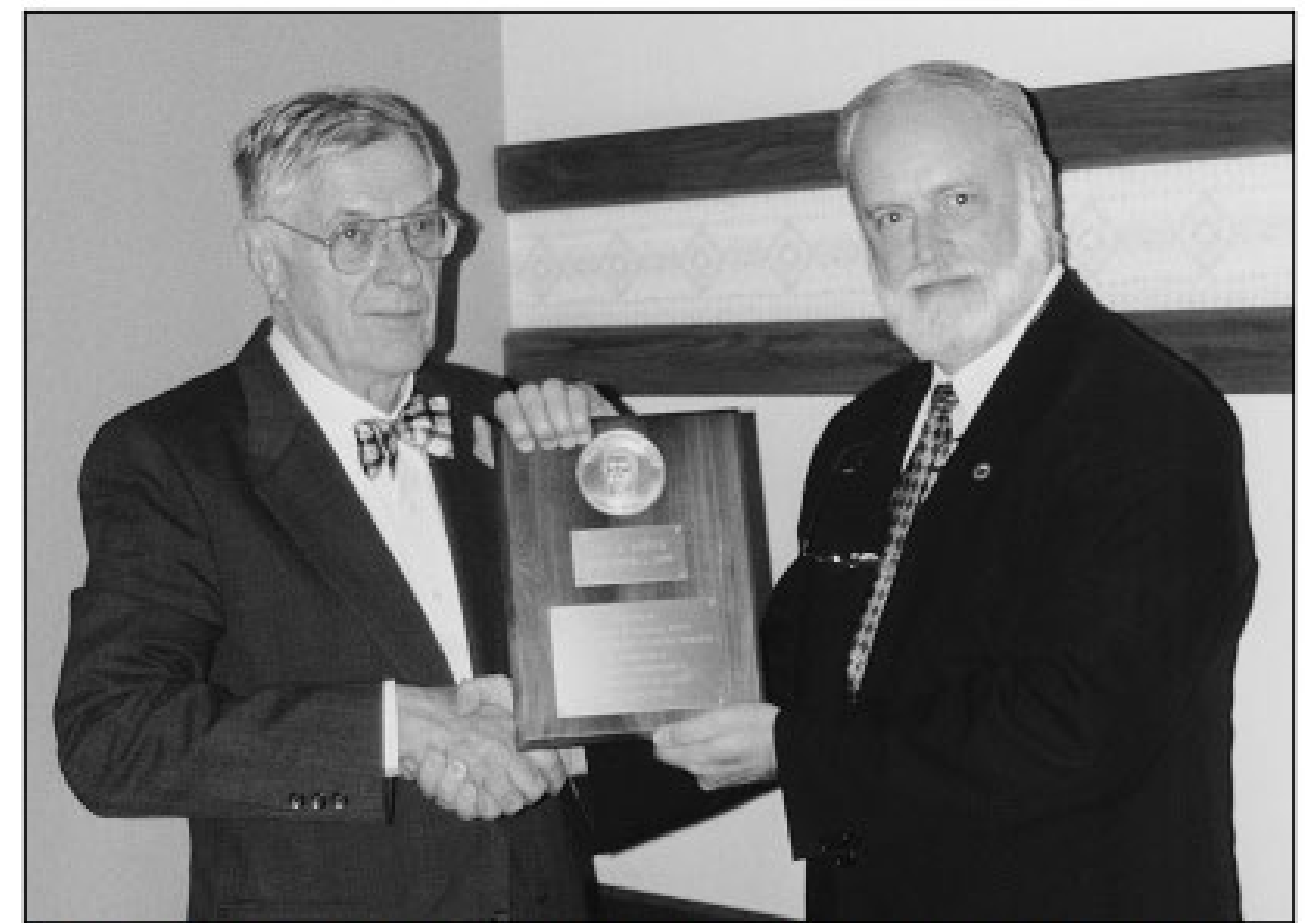

Paul Edwin Potter neceiving the Mather Medal from Division Chief Tom Berg. Photo by Dale Wilson.

1999: Presentation of the Mather Medal, for contributions to $\mathrm{OH}$ geology, by $\mathrm{OH}$ Survey Chief Tom Berg

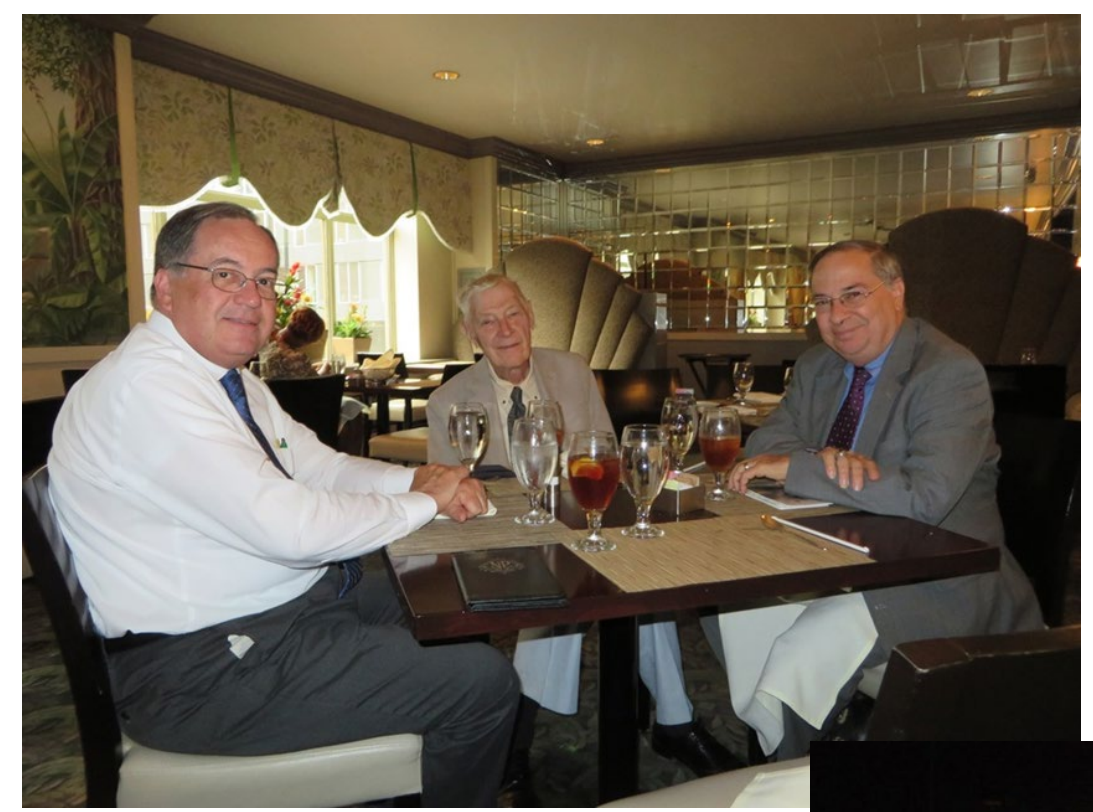

Mark Bowers, UC Engineering Asst Dean; Paul; Tim Burke, Cinti political leader, discussing Cinti infrastructure and training future government employees (ca 2015)

Distinguished service award from Petrobras 2007

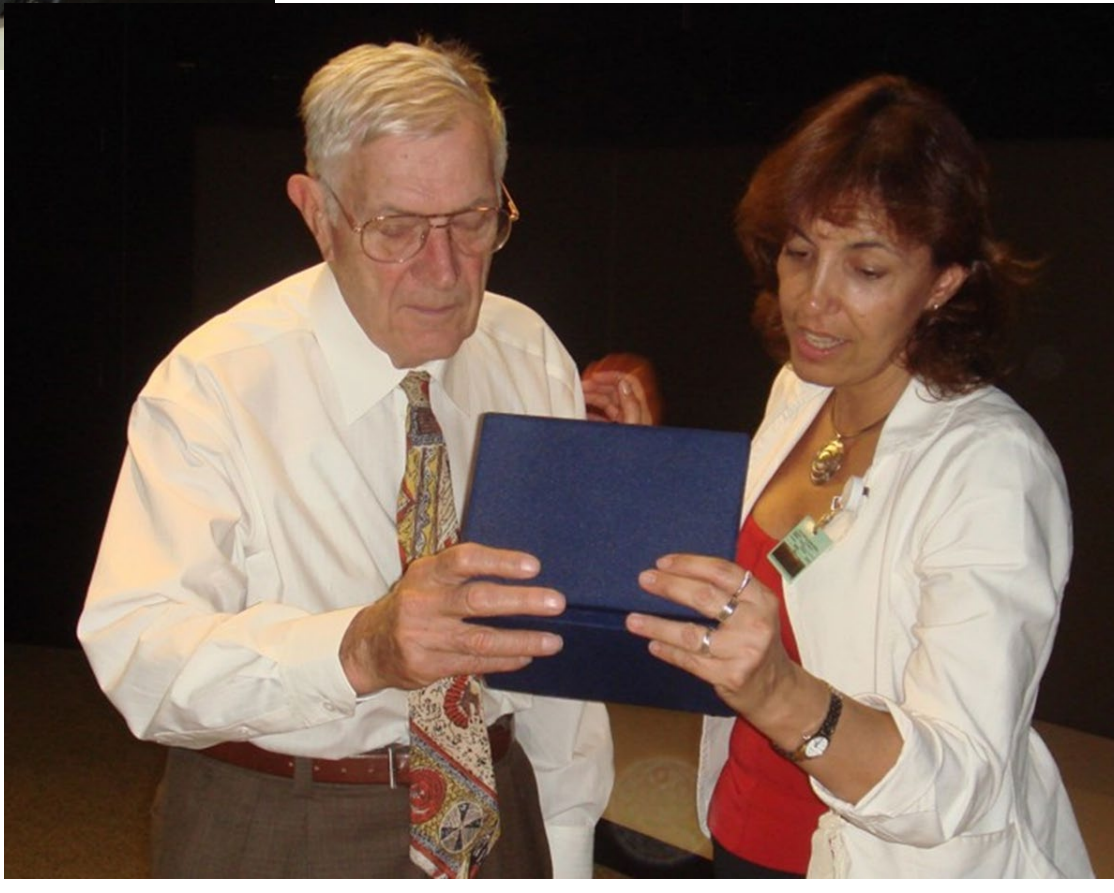




\section{COMMUNITY SERVICE: Regional and local publications}
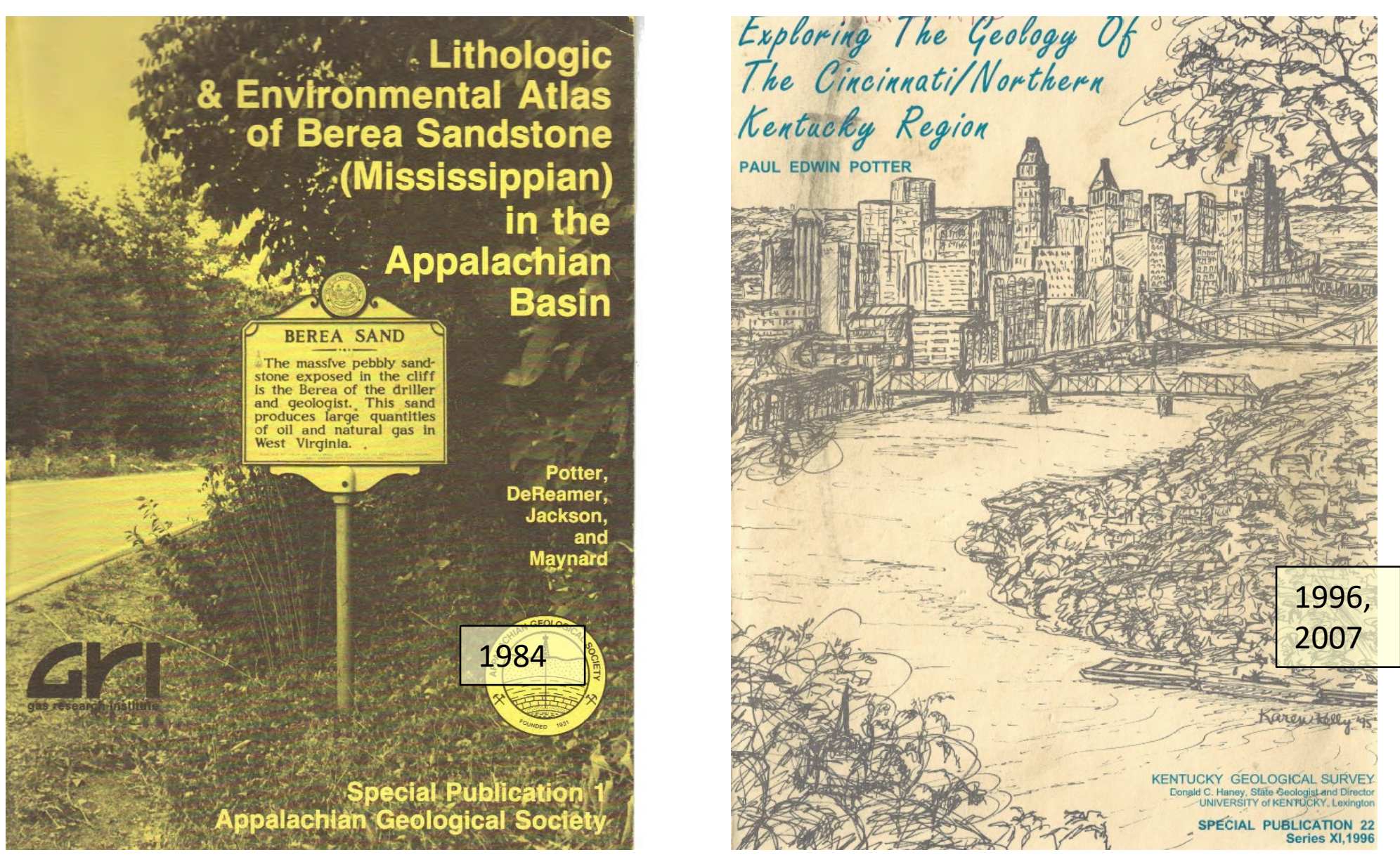

\section{Landslides and}

Your Property

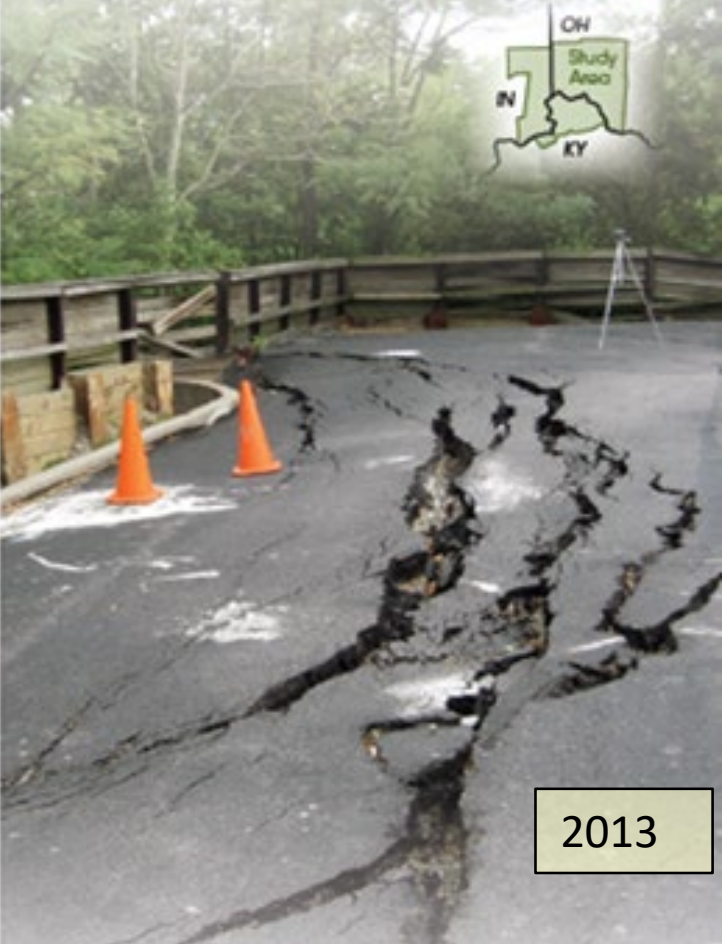

Characteristics

- Combine surface and subsurface

- Work closely with surveys

- Involve lots of graduate students

- Write for a larger audience - geologists and engineers 
Shaking things up again: Brazil 1993-2000

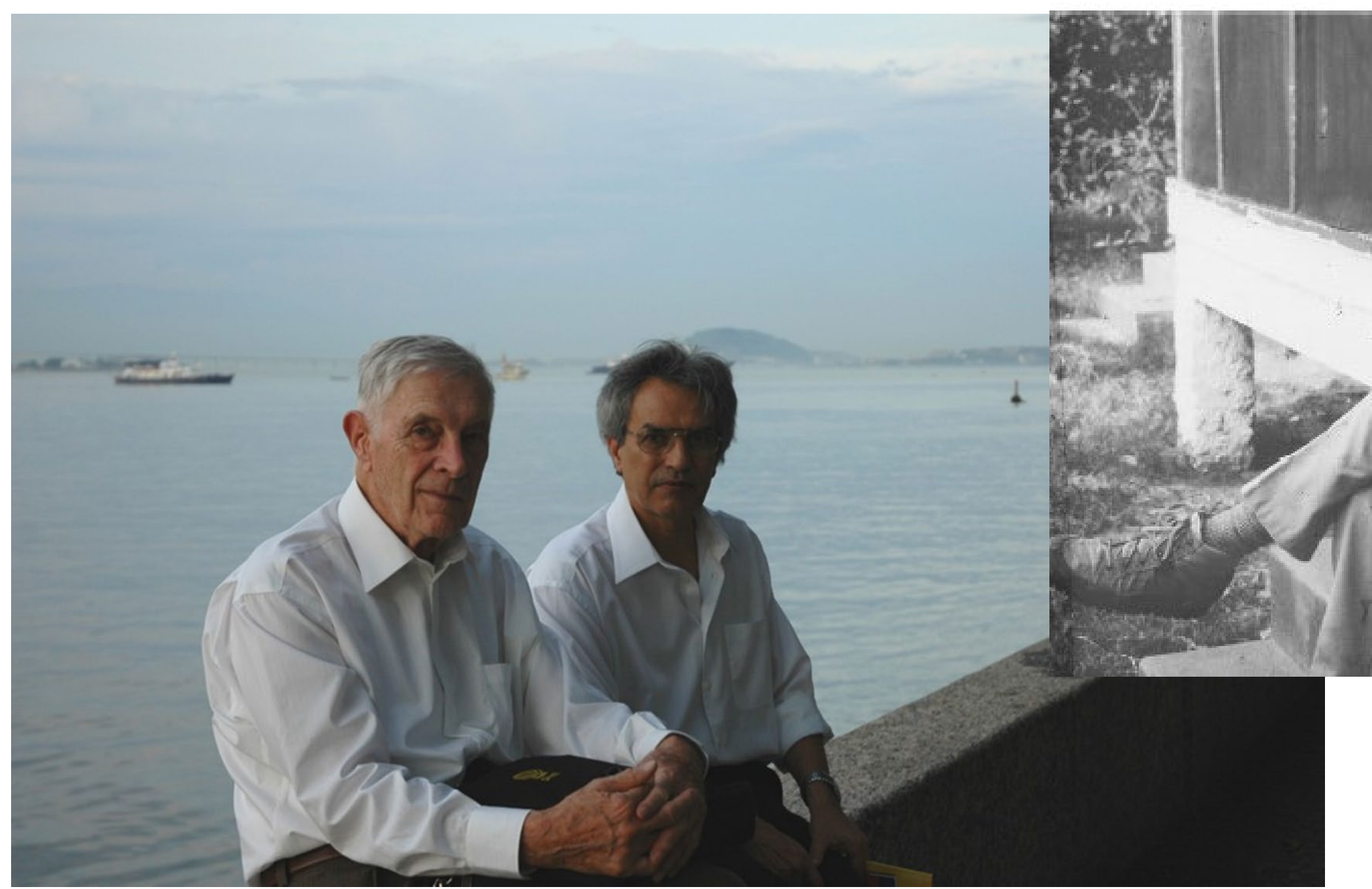

With Almerio Franca, Rio 2007

Field work on the Parana River, 1987 


\section{An example: The Botucatu Sandstone - making quartz arenites}

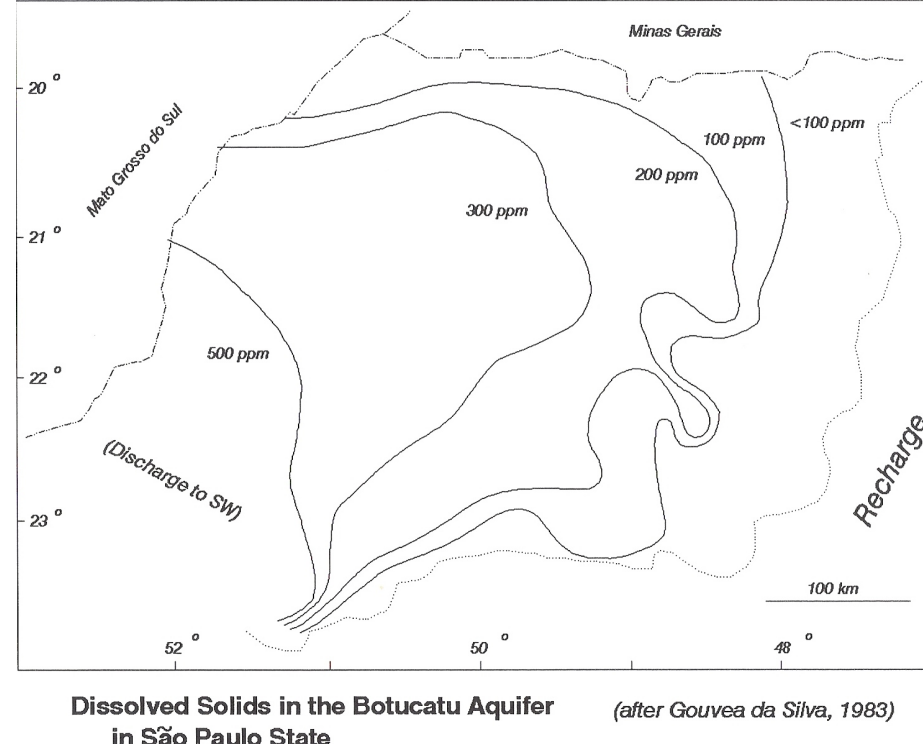

Dissolved Solids in the
in São Paulo State

Remarkable penetration of fresh groundwater into deep subsurface

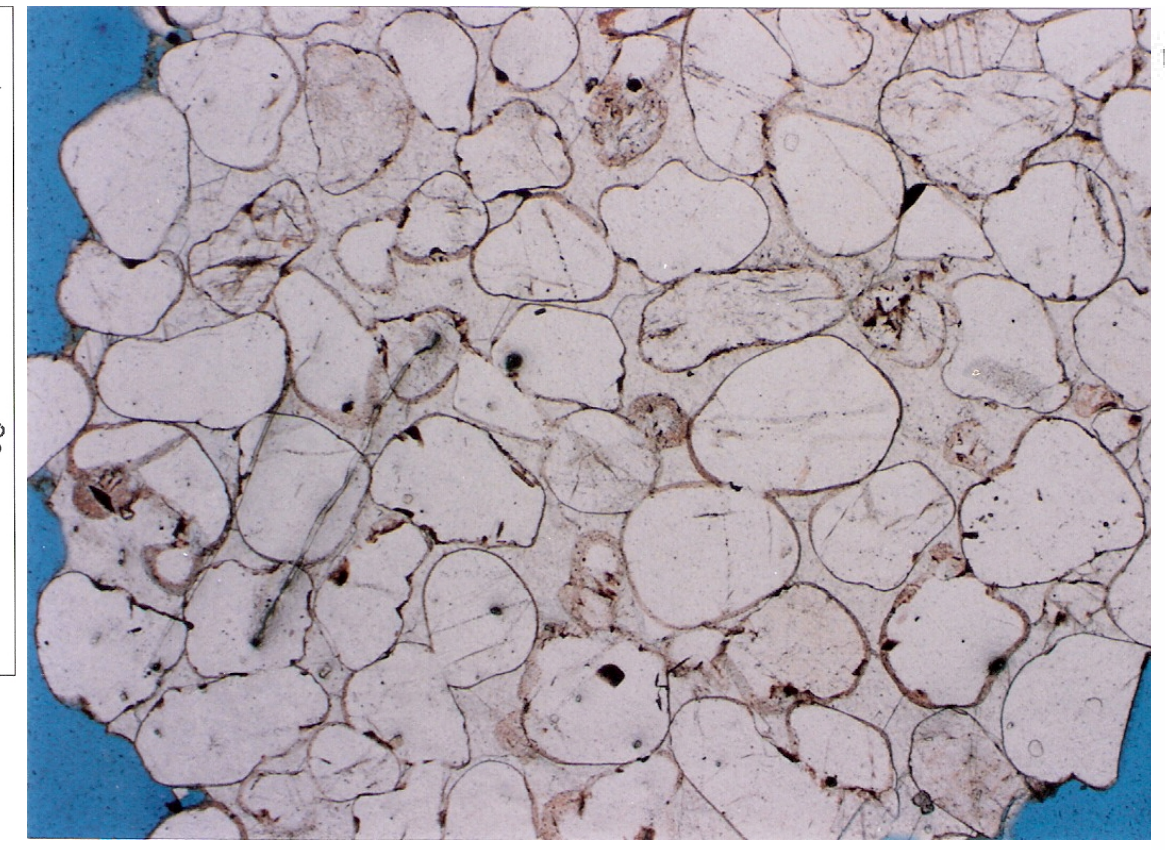

Open fabric indicates early calcite cement; hematite rims indicate desert environment

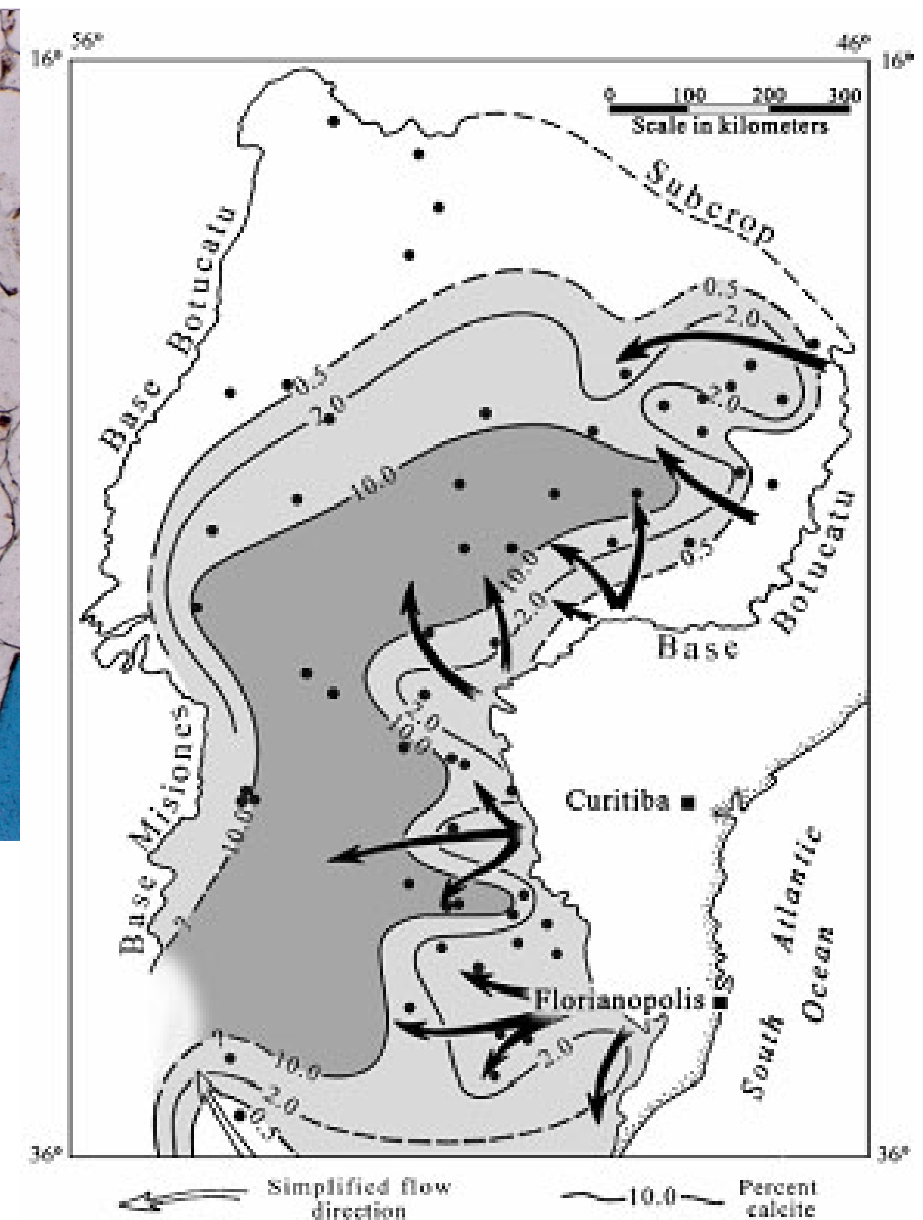

Ground water flow leaches feldspar and calcite cement from areas 100$200 \mathrm{~km}$ from outcrop 


\section{Characteristics}

- Think small - that is microscopic. Use sandstone petrology to unravel depositional and diagenetic history

- Work the whole basin - especially the subsurface

- Think outside the North Atlantic framework

- Apply locally (find groundwater supplies) and globally (what other sandstones could be like this?)

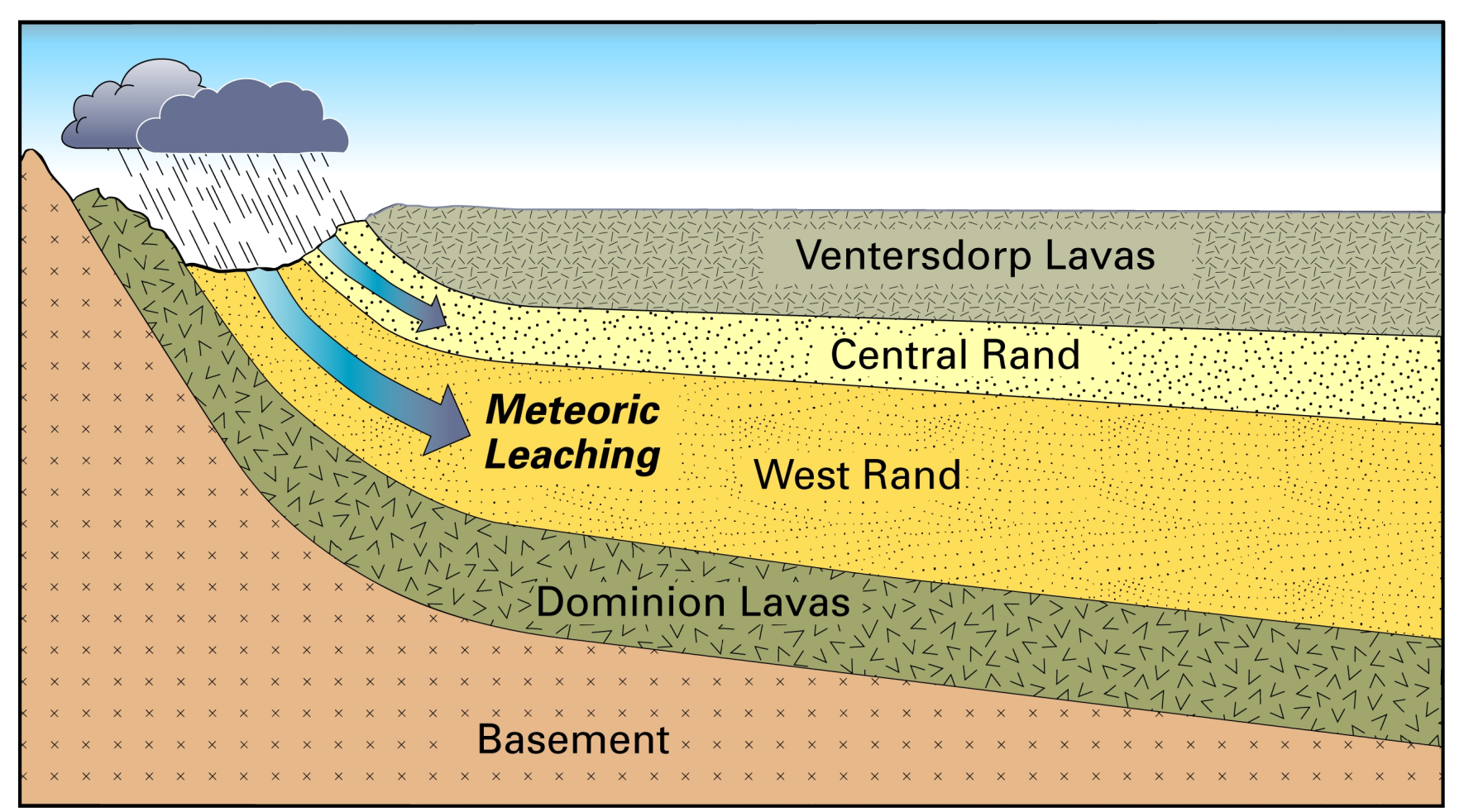




\section{The biggest project -} sands of a whole continent

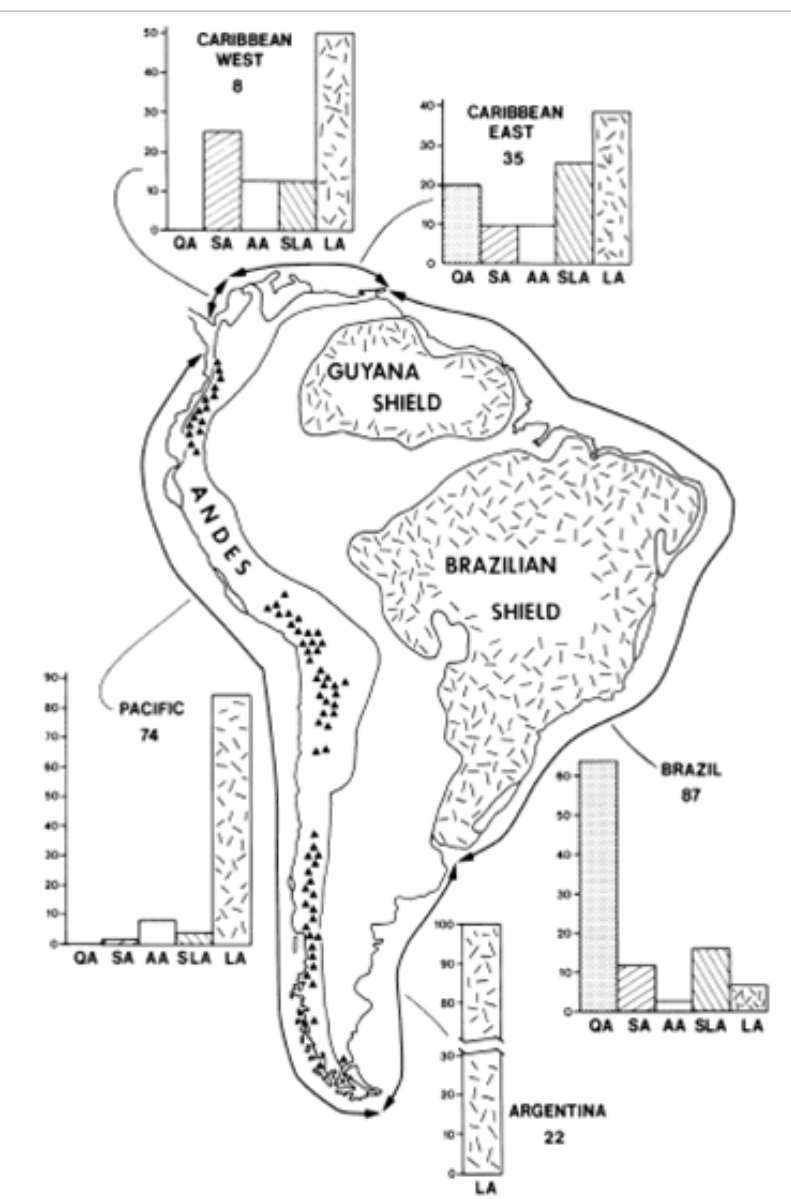

The newest tools single-zircon ages for provenance

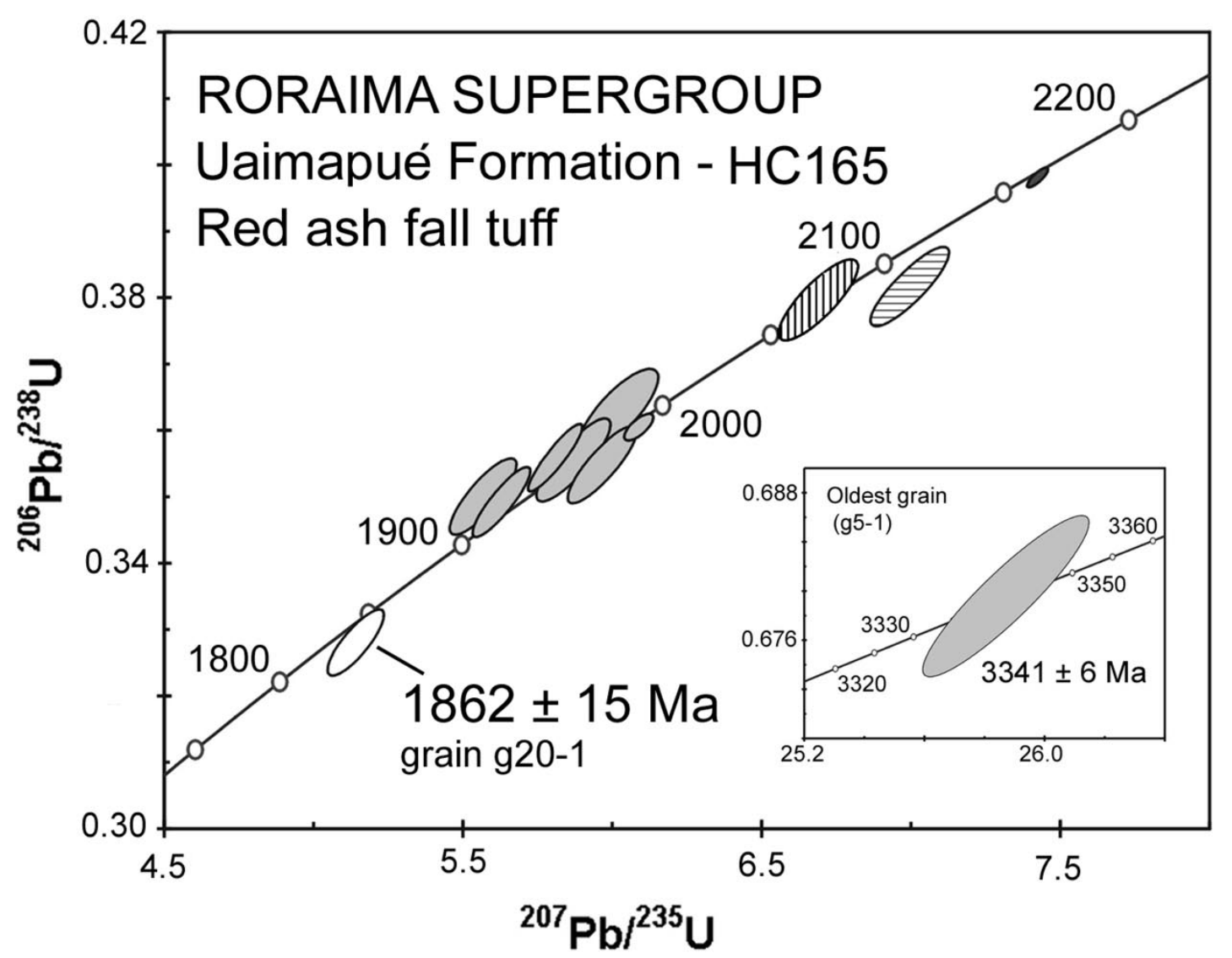




\section{Return to Cincinnati 2000-2020}

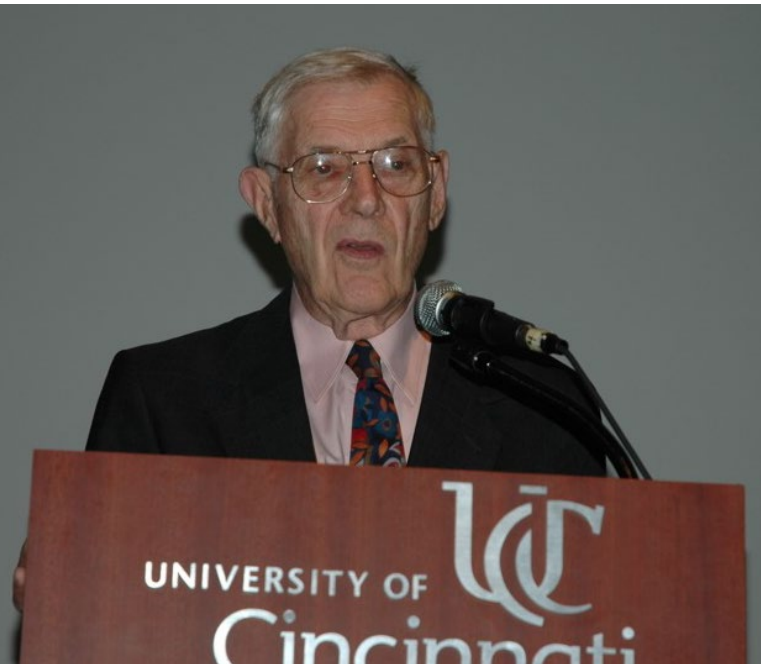

New (or renewed)

directions: the Global Miocene and the Kope Formation
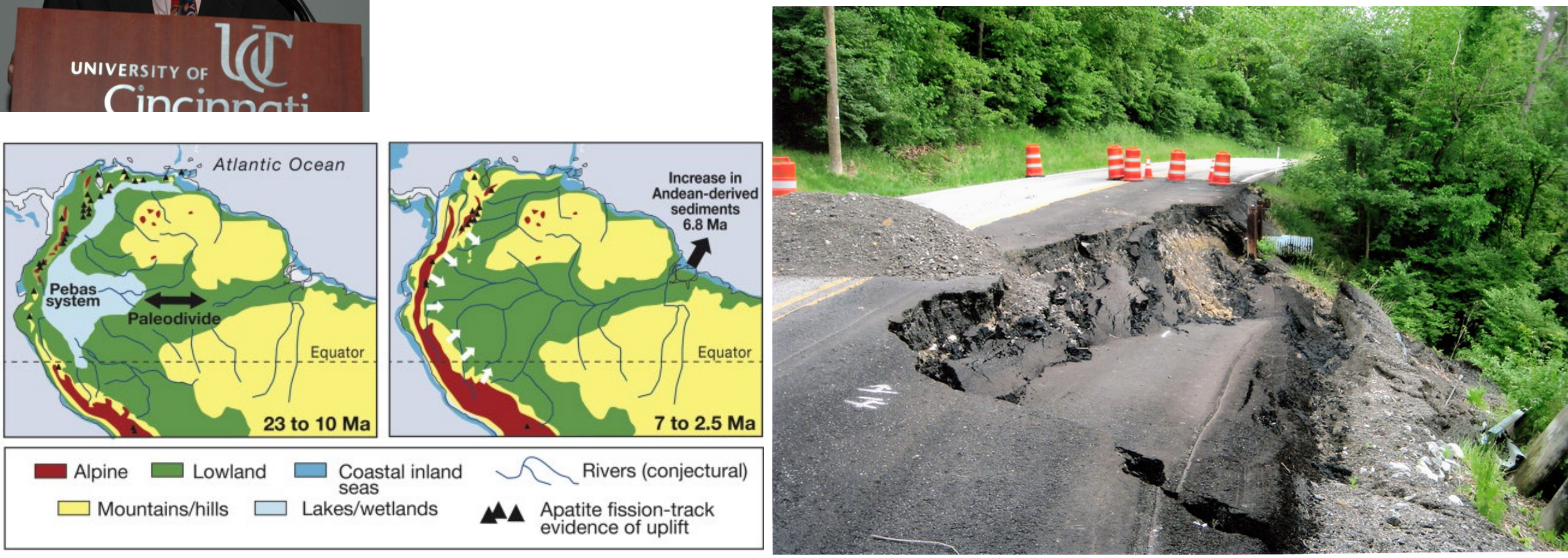

Coastal inland

$\square$ Mountains/hills

$\square$ Lakes/wetlands
4. Apatite fission-track evidence of uplift 


\section{The troublesome Kope Fmn}

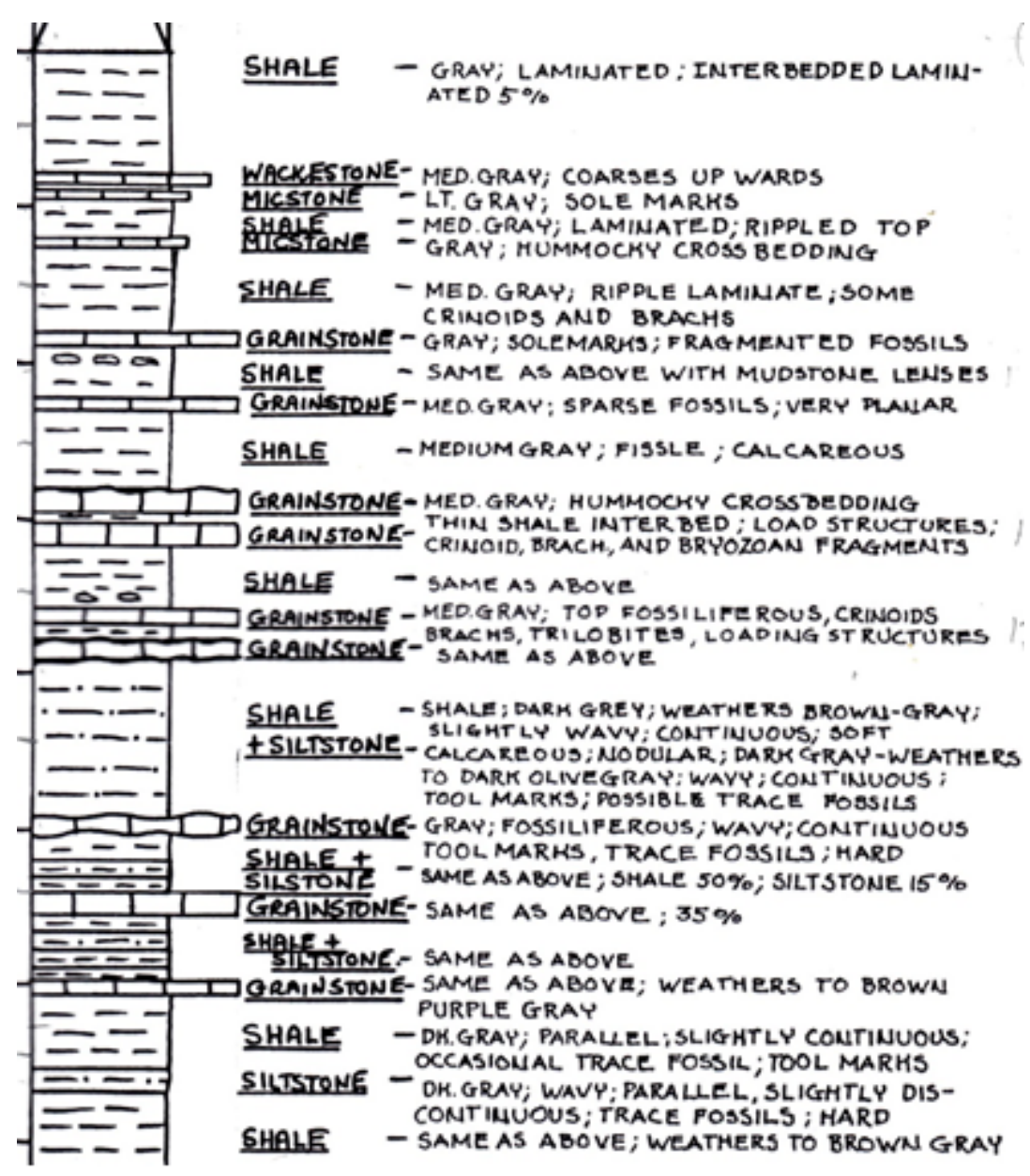

Measured section Northern KY by sedimentology class

Slake Durability (2-cycle)

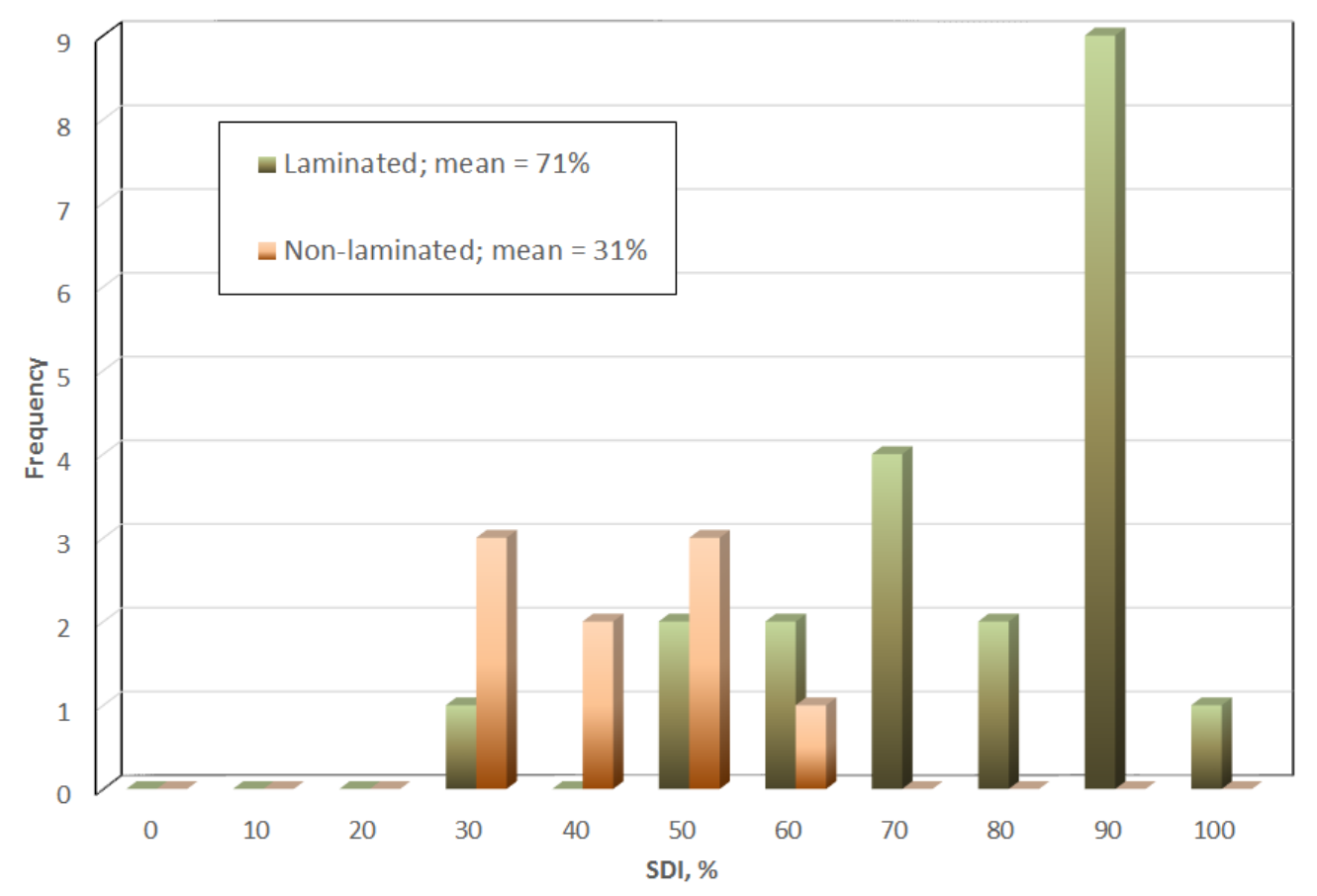

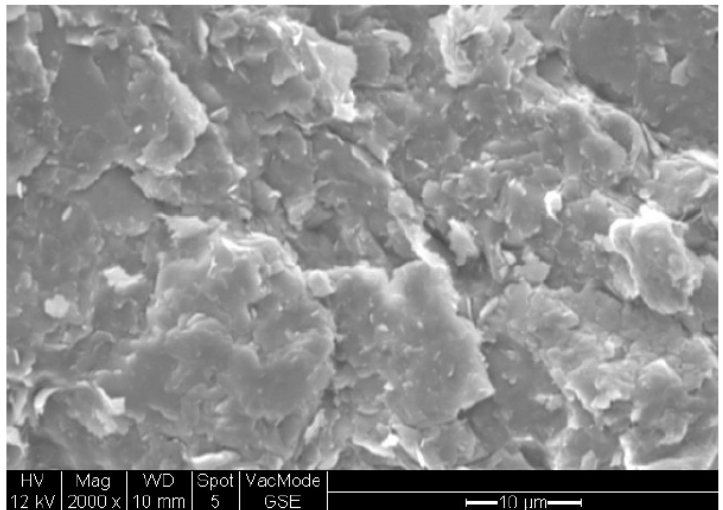

Laminated

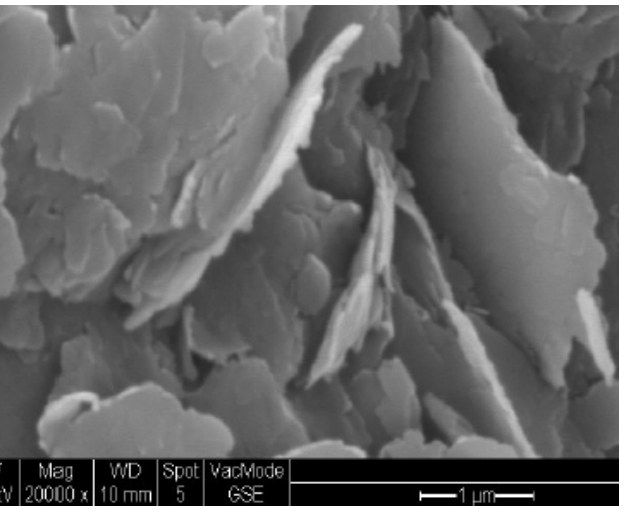

Non-laminated 


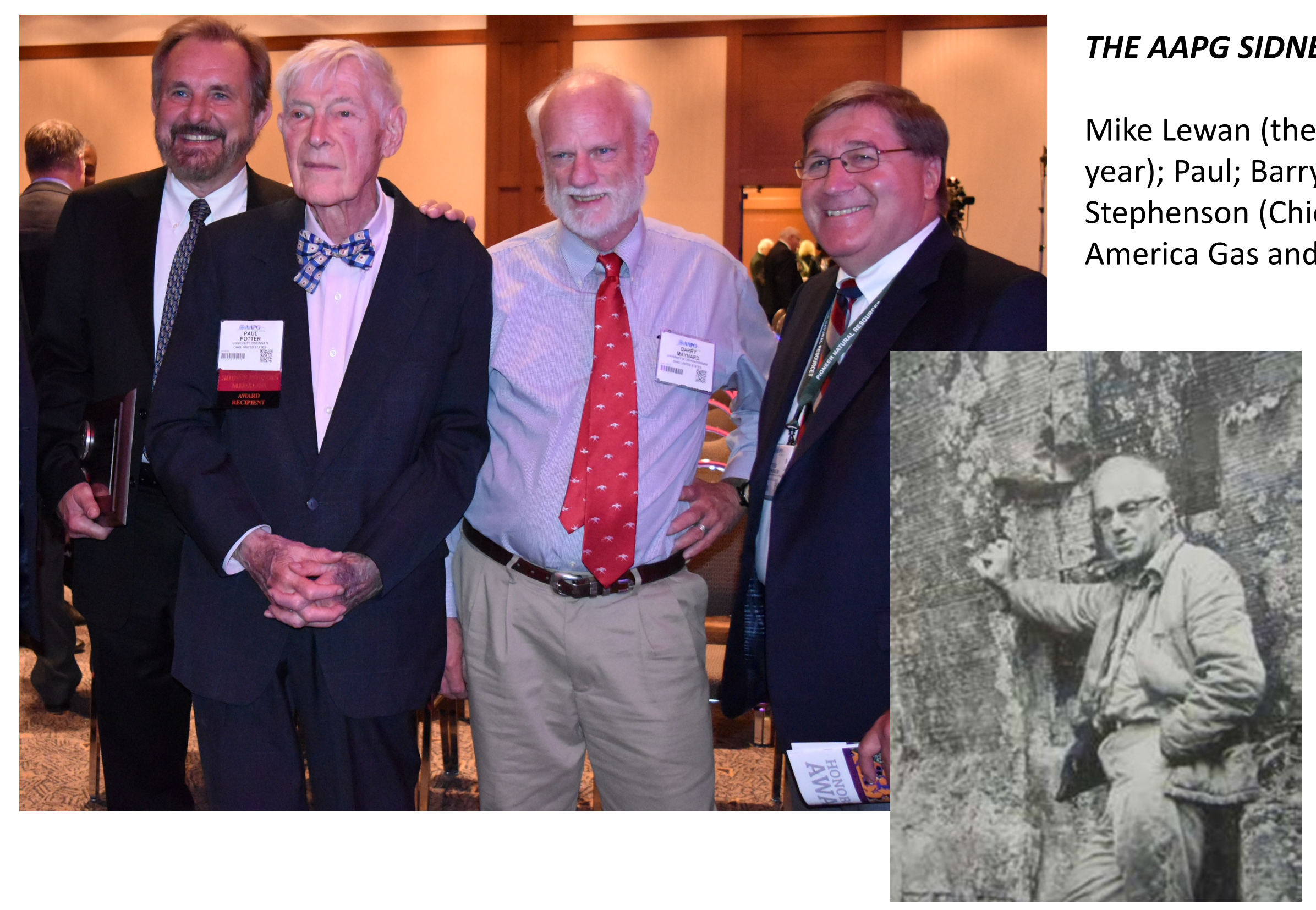

Paul, Barry, and Mike are $1^{\text {st }}, 2^{\text {nd }}$, and $3^{\text {rd }}$ generation geologists going back to Francis Pettijohn. 


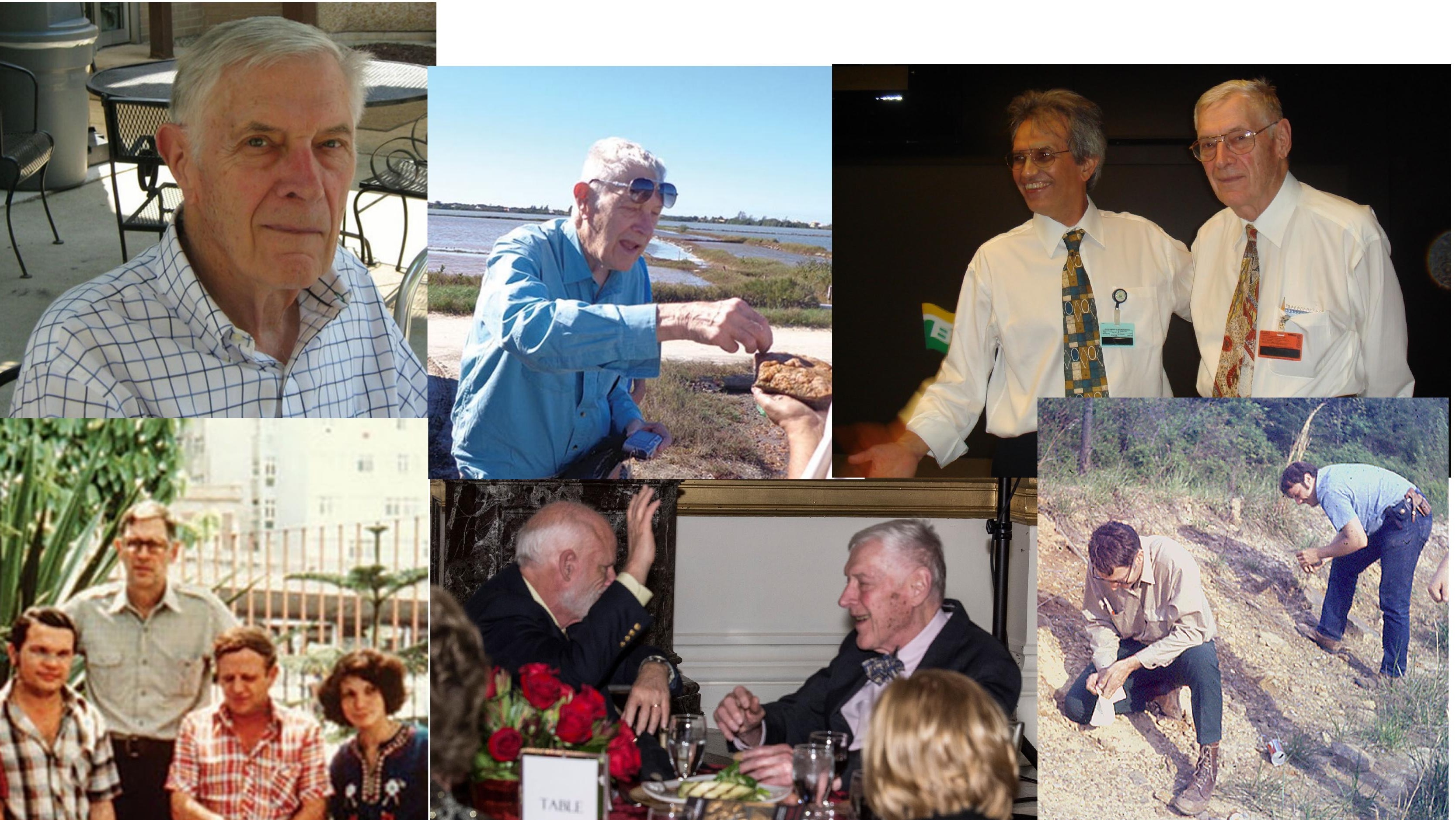




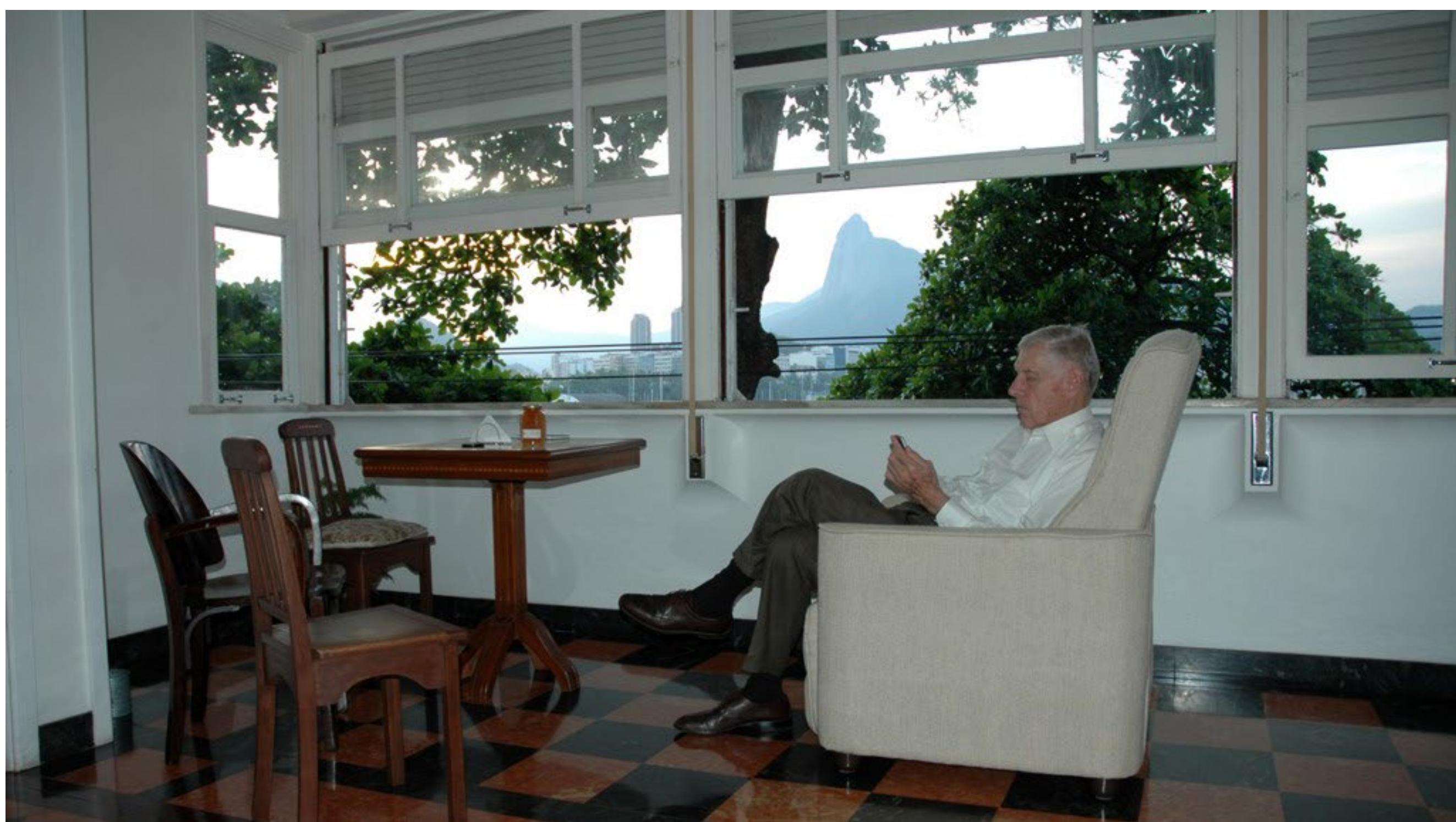

With his death, the period of "romantic geology" ends, when the geologist was an adventurer through distant and unknown places, and mapping was still his main activity. A life populated by jeeps, boats, single-engine airplanes, horses and camps, that certainly new generations will not have the opportunity to know. Prof. Potter is gone, but his mark will remain for a long time in the world of geology and GEMA. José C. Stevaux 